\title{
OSTEOCYTE DIFFERENTIATION AND THE FORMATION OF AN INTERCONNECTED CELLULAR NETWORK IN VITRO
}

\author{
M.J. Mc Garrigle ${ }^{1}$, C.A. Mullen ${ }^{1}$, M.G. Haugh ${ }^{1}$, M.C. Voisin ${ }^{1}$ and L.M. McNamara ${ }^{1 *}$ \\ ${ }^{1}$ Centre for Biomechanics Research (BMEC), Biomedical Engineering, College of Engineering and Informatics, \\ National University of Ireland, Galway
}

\begin{abstract}
Extracellular matrix (ECM) stiffness and cell density can regulate osteoblast differentiation in two dimensional environments. However, it is not yet known how osteoblast-osteocyte differentiation is regulated within a 3D ECM environment, akin to that existing in vivo. In this study we test the hypothesis that osteocyte differentiation is regulated by a $3 \mathrm{D}$ cell environment, ECM stiffness and cell density. We encapsulated MC3T3-E1 pre-osteoblastic cells at varied cell densities $\left(0.25,1\right.$ and $\left.2 \times 10^{6} \mathrm{cells} / \mathrm{mL}\right)$ within microbial transglutaminase (mtgase) gelatin hydrogels of low $(0.58 \mathrm{kPa})$ and high $(1.47 \mathrm{kPa})$ matrix stiffnesses. Cellular morphology was characterised from phalloidinFITC and 4',6-diamidino-2-phenylindole (DAPI) dilactate staining. In particular, the expression of cell dendrites, which are phenotypic of osteocyte differentiation, were identified. Immunofluorescent staining for the osteocytes specific protein DMP-1 was conducted. Biochemical analyses were performed to determine cell number, alkaline phosphatase activity and mineralisation at 2.5 hours, 3, 21 and 56 days. We found that osteocyte differentiation and the formation of an interconnected network between dendritic cells was significantly increased within low stiffness 3D matrices, compared to cells within high stiffness matrices, at high cell densities. Moreover we saw that this network was interconnected, expressed DMP-1 and also connected with osteoblast-like cells at the matrix surface. This study shows for the first time the role of the $3 \mathrm{D}$ physical nature of the ECM and cell density for regulating osteocyte differentiation and the formation of the osteocyte network in vitro. Future studies could apply this method to develop $3 \mathrm{D}$ tissue engineered constructs with an osteocyte network in place.
\end{abstract}

Keywords: Osteoblast, osteocyte, interconnected network, three dimensional, cell density, matrix stiffness, in vitro.

* Address for correspondence:

Dr. Laoise M. McNamara

Centre for Biomechanics Research (BMEC),

Biomedical Engineering,

College of Engineering and Informatics,

National University of Ireland,

Galway, Ireland,

Telephone number: (353) 91-492251

Fax number: (353) 91-563991

Email: Laoise.McNamara@nuigalway.ie

\section{Introduction}

In bone, osteocyte cells form a complex three-dimensional (3D) communication network that plays a vital role in maintaining bone health by monitoring physical cues arising during load-bearing activity and directing the activity of osteoblasts and osteoclasts to initiate bone formation and resorption (Burger and Klein-Nulend, 1999). Osteocytes are formed when cuboidal-like osteoblasts become embedded within soft secreted osteoid and start to change morphologically to a dendritic shape characteristic of an osteocyte. This transition is accompanied by a loss of cell volume (reduced organelle content) (Knothe Tate et al., 2004; Palumbo et al., 2004) and an increase in the formation and elongation of thin cytoplasmic projections that interconnect with neighbouring osteocytes within the bone ECM and osteoblasts on the surface of the bone (Palazzini et al., 1998; Palumbo, 1986; Mullen et al., 2013; Prideaux et al., 2012; Palumbo et al., 2004). Furthermore, as an osteoblast differentiates to an osteocyte, expression of the osteoblast marker enzyme alkaline phosphatase (ALP) is greatly reduced (Jee, 2001; Mikuni-Takagaki et al., 1995; Nakano et al., 2004) along with an upregulation in dentin matrix protein-1 (DMP-1) (Narayanan et al., 2003; Rios et al., 2005). During the transformation from soft secreted osteoid to a mineralised ECM, the embedded osteoblast has been shown to extend out thick cell processes that polarise towards the mineralised matrix layer. These cell processes are believed to be involved in the extrusion of calcifying matrix vesicles and hence the formation of a mineralised osteoid matrix. This is followed by the cell extending out dendrites of a longer, thinner nature towards the vascular space, which are believed to have a nutritional function (Barragan-Adjemian et al., 2006; Palumbo, 1986). It is believed that osteocyte cell processes play an important role in monitoring mechanical stimulation of the osteocytes, arising from fluid flow within the lacunarcanalicular network and direct mechanical strain of the bone cell membrane (Anderson and Knothe Tate, 2008; Han et al., 2004; Knothe Tate et al., 1998; Knothe Tate et al., 2000; Knothe Tate and Niederer, 1998; McNamara et al., 2009; Verbruggen et al., 2012; Wang et al., 2000; Wang et al., 2005; Wang et al., 2007; Weinbaum et al., 1994; You et al., 2001; Zeng et al., 1994).

Osteogenic differentiation of human mesenchymal stem cells (MSCs) and pre-osteoblasts (MC3T3-E1) has been studied on 2D surfaces (Engler et al., 2006; Przybylowski et al., 2012) and on 3D biomaterials (Correia et al., 2012; Curtin et al., 2012; Gleeson et al., 2010; Keogh et al., 2010), which act as tissue engineering (TE) scaffolds for cell attachment and tissue growth. Through these methods important cellular responses have been identified, in particular regulatory mechanisms for cell proliferation, 
migration, and matrix production, which provide information that is driving the development of approaches for regenerating bone tissue in vitro as a treatment for large bone defects. It has been shown that substrate (2D) (Engler et al., 2004; Mullen et al., 2013) and matrix (3D) (Tan et al., 2014) stiffnesses are important physical factors that induce a phenotypic shift towards osteogenic differentiation. Indeed, extracellular mechanical cues are recognised as regulators of a variety of cell behaviours such as migration (Zaman and Trapani, 2006), proliferation (Hadjipanayi et al., 2009), and differentiation (Lo et al., 2000; Tan et al., 2014). Moreover, the extracellular mechanical environment can partially direct osteogenic differentiation and mineralisation of a variety of cells including myoblasts (Tan et al., 2014), osteoblasts (Chatterjee et al., 2010), MSCs (Engler et al., 2006; Huebsch et al., 2010; Wang et al., 2012) and embryonic stem cells (Evans et al., 2009). In particular, the effect of varying 2D substrate stiffness on cultured osteoblastic cells has been shown to favour osteocyte differentiation on relatively soft ECM substrates (0.286 kPa) (Mullen et al., 2013), whereas culture on a more rigid substrate $(20-40 \mathrm{kPa})$ led to osteogenic differentiation (Engler et al., 2004).

Cell seeding density has also been shown to be a critical parameter controlling cell proliferation, ECM synthesis and osteogenic signal expression, as it dictates the paracrine signalling distance between cells (Kim et al., 2009; Mullen et al., 2013; Zhou et al., 2011). Using a 2D culture of preosteoblastic cells seeded on collagen substrates, we have recently shown that a low cell seeding density was important for dendrite formation and osteogenic differentiation, as indicated by reduced alkaline phosphatase (ALP) activity and increased mineral production (Mullen et al., 2013). In contrast, a high cell density resulted in the attainment of an osteoblastic phenotype, indicated by a spread morphology and high levels of ALP (Mullen et al., 2013).

In vivo, osteoblasts and osteocytes primarily exist within a complex three dimensional (3D) environment (Boukhechba and Balaguer, 2009), and it is known that 3D environment has a significant effect on cell morphology and geometry, as shown in NIH $3 \mathrm{~T} 3$ fibroblast (Legant et al., 2010), cardiac cells (Soares et al., 2012) and MC3T3-E1 osteoblasts (Murshid et al., 2007). The process of osteocyte dendrite formation within a 3D environment is highly dynamic, as the embedding cells repeatedly extend and retract their dendrites. These "exploratory dendrites" make transient connections with already embedded osteocytes and may allow the osteocyte to position itself an appropriate spacing from other embedded osteocytes to maintain the ordered three dimensional spacing of the osteocyte network (Dallas et al., 2013; Zhang et al., 2006). However, although osteocyte differentiation has been studied in 2D (Mullen et al., 2013), it is not known how biophysical cues, such as matrix stiffness and cell density, control the phenotypic shift from osteoblasts to osteocytes in a $3 \mathrm{D}$ environment.

In this study, we test the hypothesis that osteocyte differentiation is regulated by ECM stiffness and cell density within a 3D environment. The effect of extracellular mechanical cues in a 3D environment for osteoblastosteocyte differentiation is investigated by encapsulating
MC3T3-E1 pre-osteoblastic cells homogenously within hydrogels of varying matrix stiffnesses. To investigate the effect of cell density, osteoblast cells are cultured at varying cell densities within each of the hydrogels. Osteocyte differentiation is examined by DMP-1 staining and quantifying cellular morphology, matrix mineralisation and ALP activity.

\section{Methods}

\section{Gelatin-mtgase hydrogel preparation}

Gelatin-mtgase hydrogels, with a final concentration of $3 \% \mathrm{w} / \mathrm{v}$ gelatin, were prepared by mixing gelatin (type A, 175 Bloom, Sigma-Aldrich, Dublin, Ireland) at $37^{\circ} \mathrm{C}$ in $\alpha$ MEM (Sigma-Aldrich) culture medium containing $10 \%$ foetal bovine serum (FBS) (Sigma-Aldrich), $100 \mathrm{U} /$ $\mathrm{mL}$ penicillin (Sigma-Aldrich), $100 \mathrm{~g} / \mathrm{mL}$ streptomycin (Sigma Aldrich) and $2 \mathrm{mM}$ L-glutamine (Sigma-Aldrich), to obtain a liquid consistency for easier mixing. Gelatin suspensions were sterile filtered through a $0.22 \mu \mathrm{m}$ filter (Millipore, Cork, Ireland). Microbial transglutaminase (mtgase) (Activa WM; containing $1 \%$ mtgase; Ajinomoto foods Europe S.A.S., Mesnil-Saint-Nicaise, France) crosslinking was carried out by mixing mtgase with the gelatin suspension, allowing to vary hydrogel stiffness by using different concentrations $(0.03,0.06,0.08,0.15$ and $0.20 \%$ ) of mtgase per gram of gelatin.

\section{Gelatin-mtgase hydrogel mechanical properties}

Unconfined compression testing was used to determine the stiffness of the hydrogels exposed to different concentrations of crosslinking using a tensile tester (Z009; Zwick/Roell, Ulm, Germany) fitted with a $10 \mathrm{~N}$ load cell. Samples were prepared in silicon isolators (Sigma-Aldrich) that contained 8 wells of diameter $9 \mathrm{~mm}$ and height $2.5 \mathrm{~mm}$ ( $n=8$ per stiffness). Silicon isolators were covered with a coverslip $(50 \times 24 \mathrm{~mm})($ EU Thermo Scientific, Loughborough, UK) to produce a flat surface after gelation, see Fig.1. Samples were incubated in a bath of phosphate buffered saline (PBS) (Sigma-Aldrich) for $1 \mathrm{~h}$ at $37{ }^{\circ} \mathrm{C}$ before the coverslip and silicon isolators were removed.

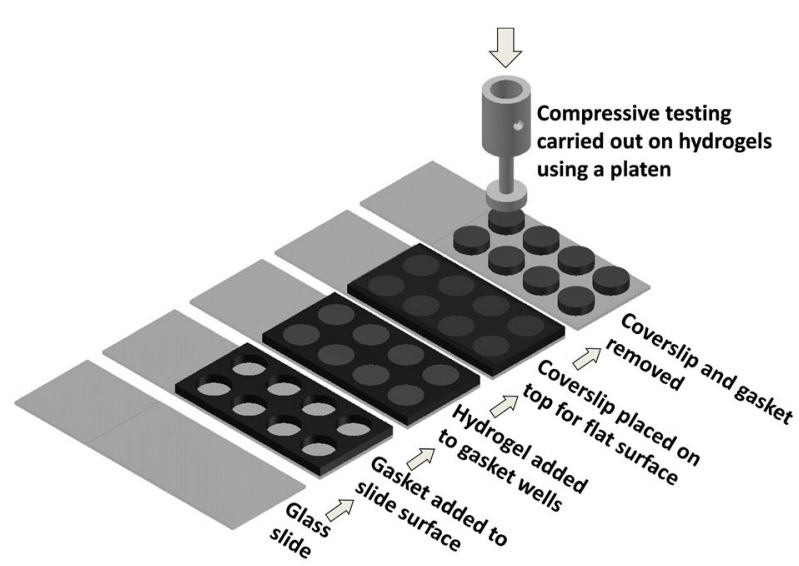

Fig. 1. Hydrogel fabrication method for mechanical testing. Unconfined compression testing was performed on samples using a custom made platen attached to a $10 \mathrm{~N}$ load cell. 
During mechanical testing the gelatin-mtgase hydrogels were held within a bath of PBS at room temperature. Testing was conducted at a strain rate of $10 \%$ per minute. The modulus was defined as the slope of a linear fit to the stress-strain curve over 2-5\% strain (Harley et al., 2007). Based on the results of these tests, a low and high matrix stiffness were chosen to examine the effects of 3D matrix stiffness on osteoblast differentiation and morphology.

\section{Cell culture embedding in 3-dimensional mtgase hydrogels}

MC3T3-E1 pre-osteoblastic cells (Sigma-Aldrich) were cultured under standard conditions $\left(5 \% \mathrm{CO}_{2}, 37^{\circ} \mathrm{C}\right)$. Cells were routinely grown to $70 \%$ confluency in T175 culture flasks (Sarstedt Ltd, Wexford, Ireland) containing $\alpha \mathrm{MEM}$ culture medium (Sigma-Aldrich), 10 \% FBS (SigmaAldrich), $100 \mathrm{U} / \mathrm{mL}$ penicillin (Sigma-Aldrich), $100 \mathrm{~g} /$ $\mathrm{mL}$ streptomycin (Sigma Aldrich) and $2 \mathrm{mM}$ L-glutamine (Sigma-Aldrich). Before encapsulating, MC3T3-E1 cells (Passage 15-16) were detached using trypsinethylenediaminetetraacetic acid (EDTA, Sigma-Aldrich) and suspended in supplemented medium at $2 \times 10^{6}$ cells/ $\mathrm{mL}$. Varying cell densities $\left(0.25,1\right.$ and $2 \times 10^{6}$ cells $/ \mathrm{mL}$, which is approximately $0.4,1$ and $\left.1.6 \times 10^{4} \mathrm{cells} / \mathrm{cm}^{2}\right)$ were prepared in separate suspensions. Cell suspensions were then mixed with $6 \%$ gelatin suspension and low and high concentrations of mtgase at a ratio of 5:4:1 (v:v:v) to give a low and high matrix stiffness. The final concentration of the mixture was $3 \% \mathrm{w} / \mathrm{v}$ gelatin, $\left(0.25,1\right.$ and $2 \times 10^{6}$ cells/ $\mathrm{mL}$ ) within mtgase concentrations of $0.03 \%$ and $0.08 \%$ per gram of gelatin. Hydrogel suspensions for biochemical assays and morphology analysis were aliquoted into 96well plates at $0.071 \mathrm{~mL} /$ well. All hydrogels had a height of $2 \mathrm{~mm}$ and were allowed to gel at $4{ }^{\circ} \mathrm{C}$ for $6 \mathrm{~min}$ before medium was added.

\section{DNA content}

DNA content was evaluated using the Hoechst 33258 DNA assay, which fluorescently labels double-stranded DNA (Sigma-Aldrich), as previously described (Haugh et al., 2011). After 2.5 h, 3, 21 and 56 d of incubation, cell laden hydrogels were washed twice with PBS, frozen and stored at $-80^{\circ} \mathrm{C}$. Samples were then thawed and digested overnight in papain digest $(100 \mathrm{mM}$ sodium phosphate buffer containing $10 \mathrm{mM}$ L-cysteine, $125 \mu \mathrm{g} / \mathrm{mL}$ papain and $5 \mathrm{mM} \mathrm{Na}{ }_{2}$ EDTA (all from Sigma Aldrich) in $\mathrm{ddH}_{2} \mathrm{O}$ at $\mathrm{pH} 6.5$ and $60^{\circ} \mathrm{C}$ ). Once the samples were digested, the biochemical assays were performed straight away or stored at $-80{ }^{\circ} \mathrm{C}$ until the assays could be performed. Briefly, $200 \mu \mathrm{L}$ of Hoechst dye solution was added to $20 \mu \mathrm{L}$ of digested samples / standards in a 96-well plate in triplicate. Fluorescence was then measured (excitation: $355 \mathrm{~nm}$; emission: $460 \mathrm{~nm}$ ) using a fluorescence spectrophotometer (Synergy HT Multi-mode microplate reader). Readings were converted to DNA content using a standard curve, according to the manufacturer's protocol, with samples containing no cells subtracted as background.

\section{Morphological analysis of cell phenotype}

Hydrogel constructs were fixed using $4 \%(\mathrm{w} / \mathrm{v})$ paraformaldehyde (Sigma-Aldrich) after $2.5 \mathrm{~h}, 21$ and $56 \mathrm{~d}$ of culture, for $1 \mathrm{~h}$ under rotation. Cells within the hydrogels were permeabilised with $2 \mathrm{mM}$ sodium chloride $(\mathrm{NaCl})$, $1.5 \mathrm{mM}$ magnesium chloride $\left(\mathrm{MgCl}_{2}\right), 16 \mathrm{mM}$ sucrose and $0.5 \%$ Triton-X100 in PBS (all from Sigma-Aldrich) for $10 \mathrm{~min}$ at $4{ }^{\circ} \mathrm{C}$ under rotation and washed with $1 \%$ PBS three times. Hydrogels were then stained with phalloidinfluorescein isothiocyanate (phalloidin-FITC) solution at $1.25 \mu \mathrm{g} / \mathrm{mL}$ (diluted 1:400, Sigma Aldrich) to stain the actin cytoskeleton and DAPI dilactate (diluted 1:2000, Sigma Aldrich) to stain the nucleus and rinsed again with $1 \%$ PBS solution. Confocal scans were taken using a confocal microscope (Olympus Fluoview FV1000) at magnifications of $10 \times$ for the hydrogel surface, $20 \times$ and $40 \times$ for cells below the hydrogel surface.

Maximum intensity images were generated from z-stacks taken at $20 \times$ magnification with a distance of $5 \mu \mathrm{m}$ between each slice for a thickness of $25 \mu \mathrm{m}$, while $40 \times$ magnification $\mathrm{z}$-stacks were taken at a distance of $2.5 \mu \mathrm{m}$ between each slice for a thickness of $10 \mu \mathrm{m}$. All stacks were obtained at the same distance of $50 \mu \mathrm{m}$ below the hydrogel surface. In total 15 stacks were obtained at each time-point, for each condition (five on each replicate hydrogel).

Cell processes were defined as cellular features composed of actin, located at the cell membrane, which extended for a distance of at least $10 \mu \mathrm{m}$ from the cell body, as previously described (Mullen et al., 2014). Cells at later time-points, day 21 and 56 that retained a strong fluorescent actin cytoskeleton and also maintained a cell body were classified as "active", while cells that demonstrated a balled up and encapsulated morphology with a cell diameter less than $15 \mu \mathrm{m}$ were classified as "dormant". Using this classification method cell morphologies were quantified as follows: (1) "dendritic" cells exhibited the small cell body and long thin cell processes associated with osteocytes, (2) "spherical" cells had no cell processes and exhibited a spherical or cuboidal morphology, (3) "dendritic interconnected" cells represented the number of cell process that formed interconnections with neighbouring cell processes and (4) "dividing" cells represented splitting cells within the hydrogel that remain connected. Cell morphology was quantified using NIH ImageJ software particle analysis. After $2.5 \mathrm{~h}$ and $21 \mathrm{~d}$ average cell span was determined from the diameter of the dendritic cell. By day 56 , individual dendrites were manually measured and average dendrite length was determined.

\section{Live cell imaging to track exploratory dendrites}

During the $56 \mathrm{~d}$ culture period live cell images of the same location within hydrogels were taken at $20 \times$ magnification using an Olympus IX50 inverted brightfield microscope. The same cell locations were identified by scoring the bottom of 96-well plates with a grid, indicating the $\mathrm{x}$ and $\mathrm{y}$ coordinate, and through focusing within the $\mathrm{z}$ plane to identity the same cells. Images were taken every 3-4 d.

\section{DMP-1 immunofluorescent staining}

DMP-1 is a secreted protein that is upregulated during osteoblast to osteocyte differentiation and has been observed in late stage osteoblast (D'Souza et al., 1997; Feng et al., 2002) and early stage osteocytes (Dallas and 
Bonewald, 2010; Lee et al., 2014; Narayanan et al., 2003; Rios et al., 2005). Immunofluorescent staining for DMP-1 was conducted to investigate the phenotypic differentiation of MC3T3-E1 cells.

Hydrogel constructs were fixed using $4 \%$ paraformaldehyde (Sigma-Aldrich) after 21 and $56 \mathrm{~d}$ of culture for $1 \mathrm{~h}$ under rotation. Cells within the hydrogels were permeabilised with $2 \mathrm{mM}$ sodium chloride $(\mathrm{NaCl})$, $1.5 \mathrm{mM}$ magnesium chloride $\left(\mathrm{MgCl}_{2}\right), 16 \mathrm{mM}$ Sucrose and $0.5 \%$ Triton-X100 in PBS (all from Sigma-Aldrich) for $10 \mathrm{~min}$ at $4{ }^{\circ} \mathrm{C}$ under rotation and washed in PBS 3 times. Hydrogel constructs were covered with a $10 \%$ bovine serum albumin (BSA) / $3 \%$ normal goat serum (NGS) (Jackson Immunoresearch) blocking solution for $1 \mathrm{~h}$ under rotation before incubation with monoclonal antiDMP1 antibody at a dilution of $1: 100$ at $4{ }^{\circ} \mathrm{C}$ overnight (Clone 8G10.3, Millipore). After washing 3 times with $1 \%$ BSA/PBS solution, samples were then treated with a Dylight ${ }^{\mathrm{TM}} 549$ conjugate goat anti-mouse secondary antibody at a dilution of 1:100 (Jackson Immunoresearch) for $1 \mathrm{~h}$ under rotation at room temperature. After secondary staining, samples were rinsed 3 times with $1 \%$ BSA/PBS solution. Hydrogels were then further counterstained with phalloidin-FITC at $1.25 \mu \mathrm{g} / \mathrm{mL}$ (diluted 1:400, Sigma Aldrich) to stain the actin cytoskeleton and DAPI dilactate (diluted 1:2000, Sigma Aldrich) to stain the nucleus and rinsed again with $1 \%$ BSA/PBS solution. Confocal scans were taken using a confocal microscope (Olympus fluoview) at $10 \times$ and $40 \times$ magnification. Z-stacks were combined together in $2 \mathrm{D}$ to form maximum intensity images. Negative controls were performed by omitting the primary antibody incubation step.

\section{Extracellular ALP content}

Extracellular alkaline phosphatase (ALP) activity was determined using a colorimetric assay of enzyme activity (SIGMAFAST $p$-NPP Kit, Sigma Aldrich), which uses $p$-nitrophenyl phosphate ( $p \mathrm{NPP})(\mathrm{nmol})$ as a phosphatase substrate, with ALP enzyme (Sigma Aldrich) as a standard. Prior to medium change, medium was removed from samples at each time-point and frozen and stored at $-80^{\circ} \mathrm{C}$, $40 \mu \mathrm{L}$ of the medium was added to a 96-well plate in triplicate with a $50 \mu \mathrm{L}$ of $p$ NPP solution, which contains both $p$ NPP and assay buffer. The samples were shielded from direct light at room temperature for $1 \mathrm{~h}$. After this, $20 \mu \mathrm{L}$ of Stop Solution ( $3 \mathrm{M} \mathrm{NaOH}$ ) was added to the wells and the plate was read at $405 \mathrm{~nm}$ in a Synergy HT Multimode microplate reader. Results were then normalised to cell number $(\mu \mathrm{g})$ as determined through the Hoescht assay outlined above and expressed as $\mathrm{nmol} / \mu \mathrm{g}$.

\section{Mineralisation}

Mineralisation within hydrogel constructs was determined from calcium deposition and measured using the Calcium Liquicolour kit (Stanbio Laboratories, Syntec, Dublin, Ireland) according to the manufacturer's protocol. After 21 and $56 \mathrm{~d}$ of incubation, cell laden hydrogels were washed twice with PBS, frozen and stored at $-80^{\circ} \mathrm{C}$. Hydrogel samples were then thawed and digested by adding $16.6 \mu \mathrm{L}$ of $6 \mathrm{M}$ hydrochloric acid (HCL) (Sigma-Aldrich) to each well and storing the solution at $4{ }^{\circ} \mathrm{C}$, when completely dissolved HCL concentration was adjusted to $0.5 \mathrm{M} \mathrm{HCL}$ by adding $183.4 \mu \mathrm{L}$ of $\mathrm{ddH}_{2} \mathrm{O}$ to each sample. $10 \mu \mathrm{L}$ each of the digested samples and assay standard was added to a 96-well plate and $200 \mu \mathrm{L}$ of the working solution. The plate was read on a synergy HT Multi-mode microplate reader at an absorbance of $550 \mathrm{~nm}$ as previously described.

\section{Statistics}

All biochemical experiments were conducted in biological triplicate with two independent experiments run for a total of $n=6$. Cell morphology experiments were conducted in duplicate with two independent experiments run for a total of $n=4$. Results are expressed as mean \pm standard deviation. For all the biochemical analysis two-way analysis of variance (ANOVA) was conducted, followed by pair-wise multiple comparison procedure (Tukey's HSD test). All analyses were performed with Graphpad Prism 6 (GraphPad software, San Diego, USA). For all comparisons, the level of significance was $p \leq 0.05$.

\section{Results}

\section{Compressive modulus}

Compressive testing of varied stiffness of hydrogels showed an increase in stiffness with varied cross-linking concentration after incubation for $1 \mathrm{~h}$ at $37^{\circ} \mathrm{C}$, see Fig. 2. Mtgase hydrogels containing $0.03,0.06,0.08,0.15$, $0.2 \%$ mtgase had compressive moduli of $0.58 \pm 0.1$, $0.84 \pm 0.1,1.47 \pm 0.3,3.05 \pm 0.2$ and $3.03 \pm 0.4 \mathrm{kPa}$ respectively. The effect of increasing cross-linking density on hydrogel stiffness reached a plateau at $0.15 \%$ mtgase crosslinking. We sought to encapsulate cells in a similar mechanical environment to our previous studies using $2 \mathrm{D}$ substrates $(\sim 0.3 \mathrm{kPa})$, which were shown to elicit osteoblast-osteocyte differentiation (Mullen et al., 2013). The compressive moduli $0.58 \mathrm{kPa}$ was the lowest achievable stiffness in this $3 \mathrm{D}$ environment, while a higher matrix stiffness $(1.47 \mathrm{kPa})$ was selected from the gels that were crosslinked at different densities, see Fig. 2, on the basis that it was statistically significantly higher matrix stiffness $(1.47 \mathrm{kPa})$ compared to the low matrix stiffness.

\section{DNA content}

DNA content increased significantly in all matrix stiffness and cell density groups from $2.5 \mathrm{~h}$ to $56 \mathrm{~d}$ of culture $(p<0.0001)$, see Fig. 3. By day 56 in the medium cell density group $\left(1 \times 10^{6}\right.$ cells $\left./ \mathrm{mL}\right)$ a significant difference was observed between the low and high matrix stiffness $(3.28 \pm 1.02 \mu \mathrm{g} v s .2 .53 \pm 0.55 \mu \mathrm{g}, p<0.03)$.

\section{Morphological analysis of cell phenotype}

MC3T3-E1 morphology and dendritic cell span after $2.5 \mathrm{~h}$ MC3T3-E1 cells cultured at low and medium cell densities within low stiffness matrices $(0.58 \mathrm{kPa})$ showed a similar morphological pattern with approximately $81.5 \%$ classed as spherical and $18.5 \%$ as having a dendritic morphology after $2.5 \mathrm{~h}(p<0.0001)$. However, cells cultured within a high stiffness matrix $(1.47 \mathrm{kPa})$ at a low and medium cell density were classified as being approximately $99 \%$ spherical and $1 \%$ dendritic $(p<0.0001)$. In the 
Fig. 2. Mechanical properties of a $3 \%$ Gelatin hydrogel crosslinked with 0.15 , $0.03,0.06,0.08,0.15,0.2 \%$ mtgase after $1 \mathrm{~h}$ of incubation at $37{ }^{\circ} \mathrm{C}, n=8$ per group. ${ }^{\mathrm{a}} p<0.05$ relative to $0.03 \%$ mtgase hydrogel.
Fig. 3. DNA content of each group at $2.5 \mathrm{~h}$, 3, 21 and $56 \mathrm{~d}(n=6$ samples per group per time-point). ${ }^{\mathrm{a}} p<0.05$ representing a statistical difference between low $(0.58 \mathrm{kPa})$ and high $(1.47 \mathrm{kPa})$ stiffness. Error bars denote standard deviation.
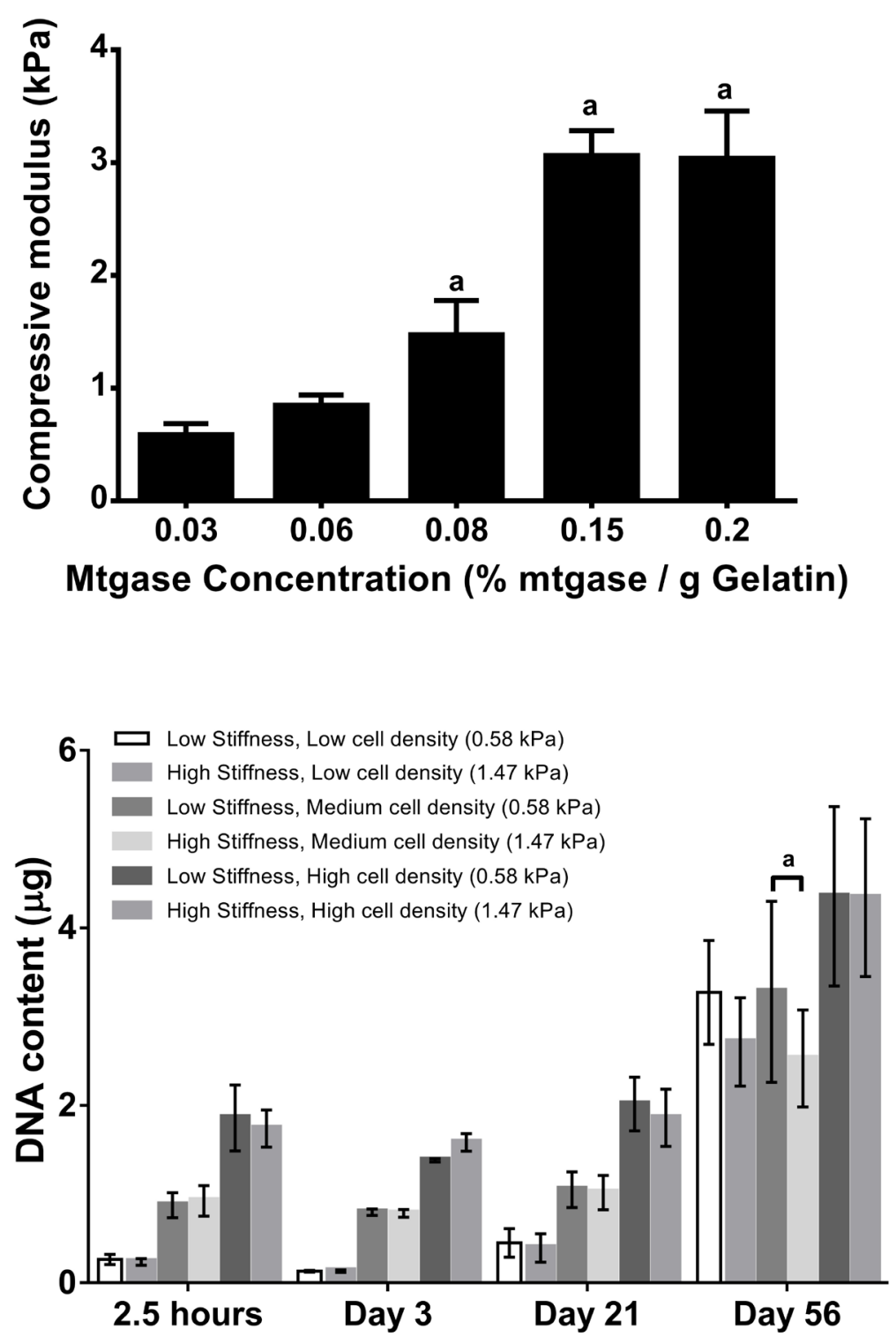

high cell density groups, within a low stiffness hydrogel $(0.58 \mathrm{kPa})$, cells were classed to be $71.5 \%$ spherical and $28.5 \%$ dendritic $(p<0.0001)$. In contrast, cells within the high stiffness matrices were classed as $97 \%$ spherical and $3 \%$ dendritic $(p<0.0001)$. Furthermore, for all cell density groups a larger percentage of dendritic cells were observed in the low stiffness matrices compared to the higher stiffness ( $p<0.0012$ ), see Fig. 4A for representative images and Fig. 4B for summarised results.

After $2.5 \mathrm{~h}$, dendritic cell span in the low stiffness matrices within each cell density had similar cell span lengths, though not significantly different, $58 \mu \mathrm{m}$ in the low cell density, $56 \mu \mathrm{m}$ in the medium cell density and $64 \mu \mathrm{m}$ in the high cell density, while no change occurred in the higher matrix stiffness hydrogels remaining at approximately $24 \mu \mathrm{m}$, see Fig. $4 \mathbf{C}$.

MC3T3-E1 morphology and dendritic cell span after $21 d$ For a low cell density and a low stiffness matrix, $52 \%$ of the cells were classified as spherical, while $48 \%$ of cells were dendritic after $21 \mathrm{~d}$. In contrast, for a high stiffness matrix, $82.6 \%$ of cells were spherical, while $17.4 \%$ of cells were dendritic $(p<0.0001)$. Cells cultured at medium and high cell densities within a low stiffness matrix showed a similar morphological pattern with approximately $24 \%$ classed as spherical and $76 \%$ as dendritic morphology for both seeding densities $(p<0.0005)$. In contrast within the high stiffness matrix, at a medium and high cell density, approximately $94 \%$ cells were spherical and $6 \%$ dendritic $(p<0.0001)$. Additionally, all cell density groups showed a significant increase in the percentage of dendritic cells in the low stiffness matrices compared to the high stiffness $(p<0.0386)$, see Fig. 5A for representative images and Fig. 5B for summarised results.

Dendritic cell span in the low stiffness matrices showed a trend of increasing as cell density increased though not significantly different. Specifically the cell span was $60.1 \mu \mathrm{m}$ in the low cell density, $67.7 \mu \mathrm{m}$ in the medium cell density and $82.2 \mu \mathrm{m}$ in the high cell density. A smaller change occurred in higher stiffness matrices, $46.7 \mu \mathrm{m}$ in the 


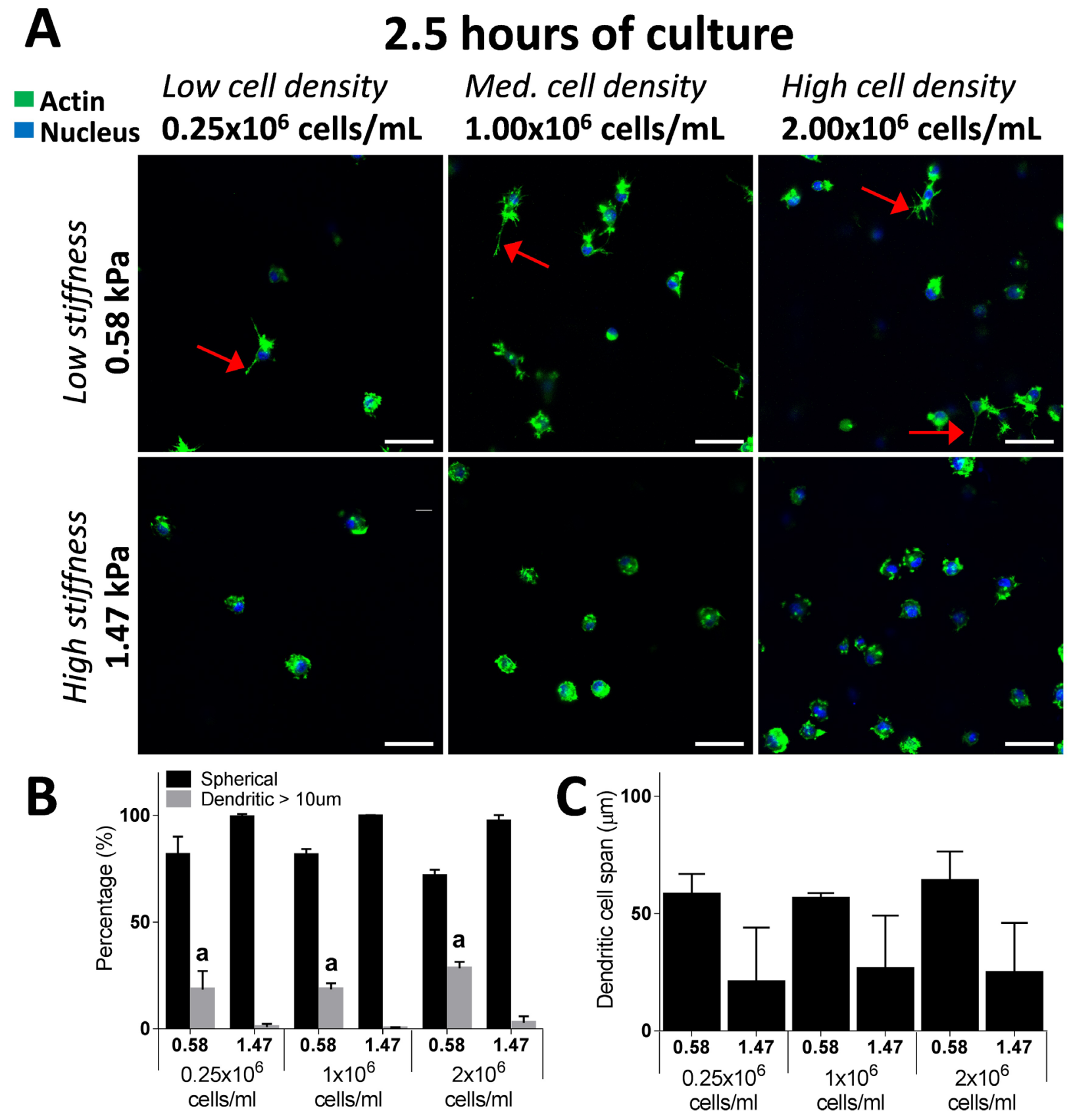

Fig. 4. Actin staining of cell morphology after $2.5 \mathrm{~h}$ of culture comparing spherical vs. dendritic (Red arrows) morphology (A). Also shown is the percentage of spherical vs. dendritic cells $(\mathbf{B})$ and average dendritic cell span $(\mathbf{C})$ within low $(0.58 \mathrm{kPa})$ and high $(1.47 \mathrm{kPa})$ stiffness matrices. ${ }^{\mathrm{a}} p<0.05$ representing a statistical difference between low $(0.58 \mathrm{kPa})$ and high $(1.47 \mathrm{kPa})$ stiffness at the same density group. Scale bar $=50 \mu \mathrm{m}$, same for all images.

low cell density, $50.3 \mu \mathrm{m}$ in the medium cell density and $56.4 \mu \mathrm{m}$ in the high cell density, though not significantly different. A significant difference was observed between the low and high matrix stiffness at the high cell density group ( $p<0.0491)$, see Fig. 5C.

MC3T3-E1 morphology, dendritic cell length and interconnections after $56 \mathrm{~d}$

By $56 \mathrm{~d}$, in all hydrogel groups, cells formed a confluent layer at the surface of the hydrogels, see Fig. 6 and Fig. 7. Below the surface, at low and medium cell densities within a low stiffness matrix, cells showed similar morphology patterns with approximately $24 \%$ spherical and $76 \%$ dendritic $(p<0.0001)$. However, cells cultured within a high stiffness matrix at a low and medium cell density were classified to be approximately $60 \%$ spherical and $40 \%$ dendritic, though not significantly different. For a high cell density and a low stiffness matrix, $14.6 \%$ were classed as spherical, while $85.4 \%$ were dendritic $(p<0.0001)$. In contrast, cells within a high stiffness matrix were $64.6 \%$ spherical and $34.4 \%$ dendritic $(p<0.0148)$. Similarly to day 21, a larger percentage of dendritic cells were observed in the low stiffness matrices compared to the high stiffness in all cell density groups $(p<0.0093)$, see Fig. $8 \mathbf{A}$ for representative images and Fig. $8 \mathbf{B}$ for summarised results. 


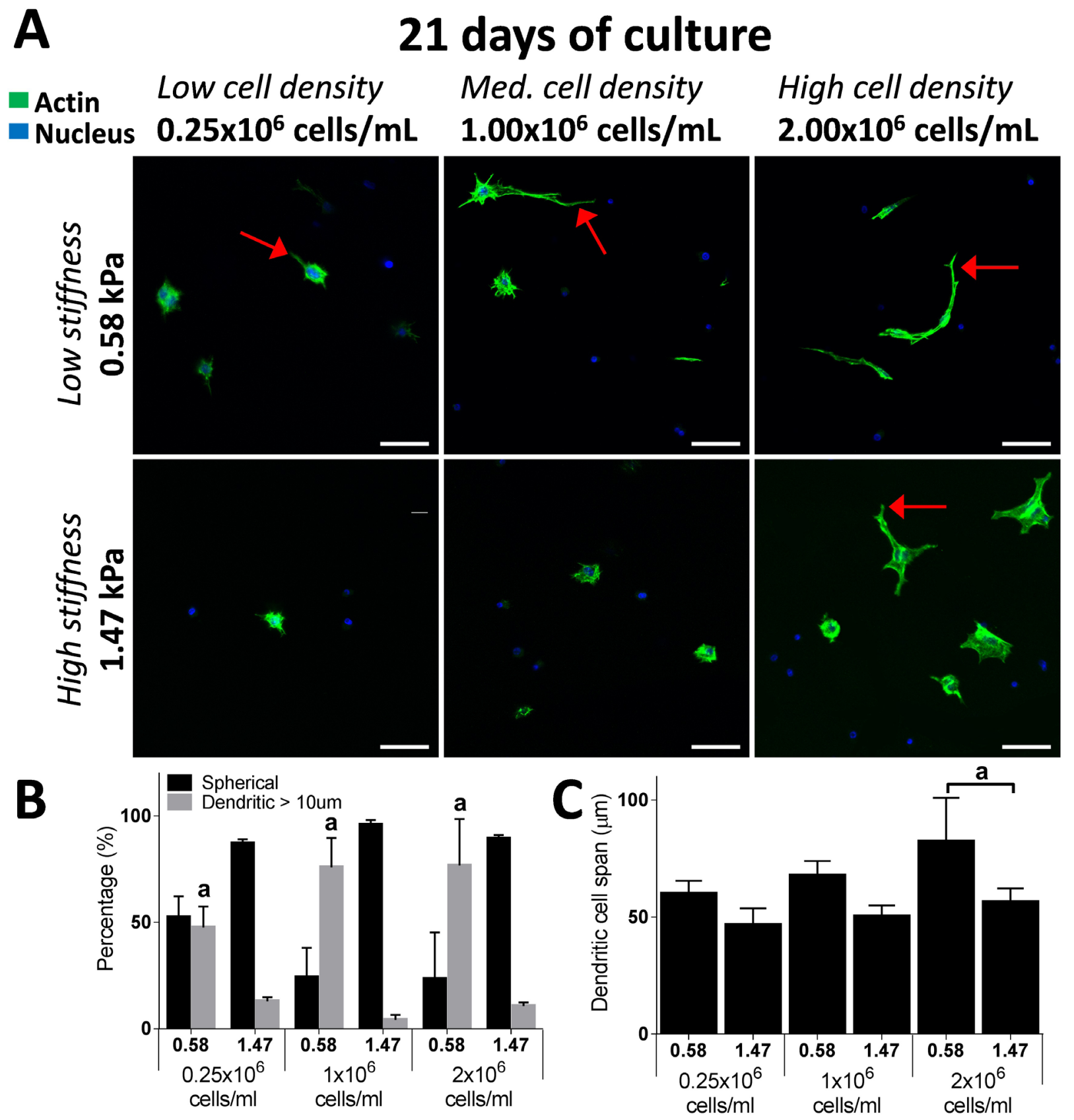

Fig. 5. Actin staining of cell morphology after $21 \mathrm{~h}$ of culture comparing spherical vs. dendritic (Red arrows) morphology (A). Also shown is the percentage of spherical vs. dendritic cells $(\mathbf{B})$ and average dendritic cell span $(\mathbf{C})$ within low $(0.58 \mathrm{kPa})$ and high $(1.47 \mathrm{kPa})$ stiffness matrices. ${ }^{\mathrm{a}} p<0.05$ representing a statistical difference between low $(0.58 \mathrm{kPa})$ and high $(1.47 \mathrm{kPa})$ stiffness at the same density group. Scale bar $=50 \mu \mathrm{m}$, same for all images.

At $56 \mathrm{~d}$, average individual dendrite length within the low stiffness matrices was $46.2 \mu \mathrm{m}$ in the low cell density, $53.9 \mu \mathrm{m}$ in the medium cell density and $67.2 \mu \mathrm{m}$ in the high cell density. Dendrite length in higher stiffness matrices was $35.7 \mu \mathrm{m}$ in the low cell density, $36.9 \mu \mathrm{m}$ in the medium cell density and $29.3 \mu \mathrm{m}$ in the high cell density. Furthermore, a significant difference was observed between the low and high matrix stiffness at the high cell density group $(p<0.0095)$, see Fig. 8 C.

\section{Cell interconnections after $56 \mathrm{~d}$}

Cells at a high cell density within a low stiffness matrix had the highest number of interconnections between neighbouring dendritic cells compared to the high stiffness matrix at the same density $(p<0.037)$. Cells were classified as $38.8 \%$ interconnected, whereas $30.9 \%$ were unconnected and $30.3 \%$ connected as dividing cells. For the higher stiffness matrix at the same cell density $4.6 \%$ of cells were interconnected, $89.1 \%$ were unconnected and $6.3 \%$ connected as dividing cells. At a medium cell density, within a low stiffness matrix, cells were approximately classified as $16.5 \%$ interconnected, while $32 \%$ were unconnected and $51.5 \%$ connected as dividing cells. For the higher stiffness matrix at the same cell density $2.8 \%$ of cells were interconnected, $71.9 \%$ were unconnected and $25.3 \%$ connected as dividing 


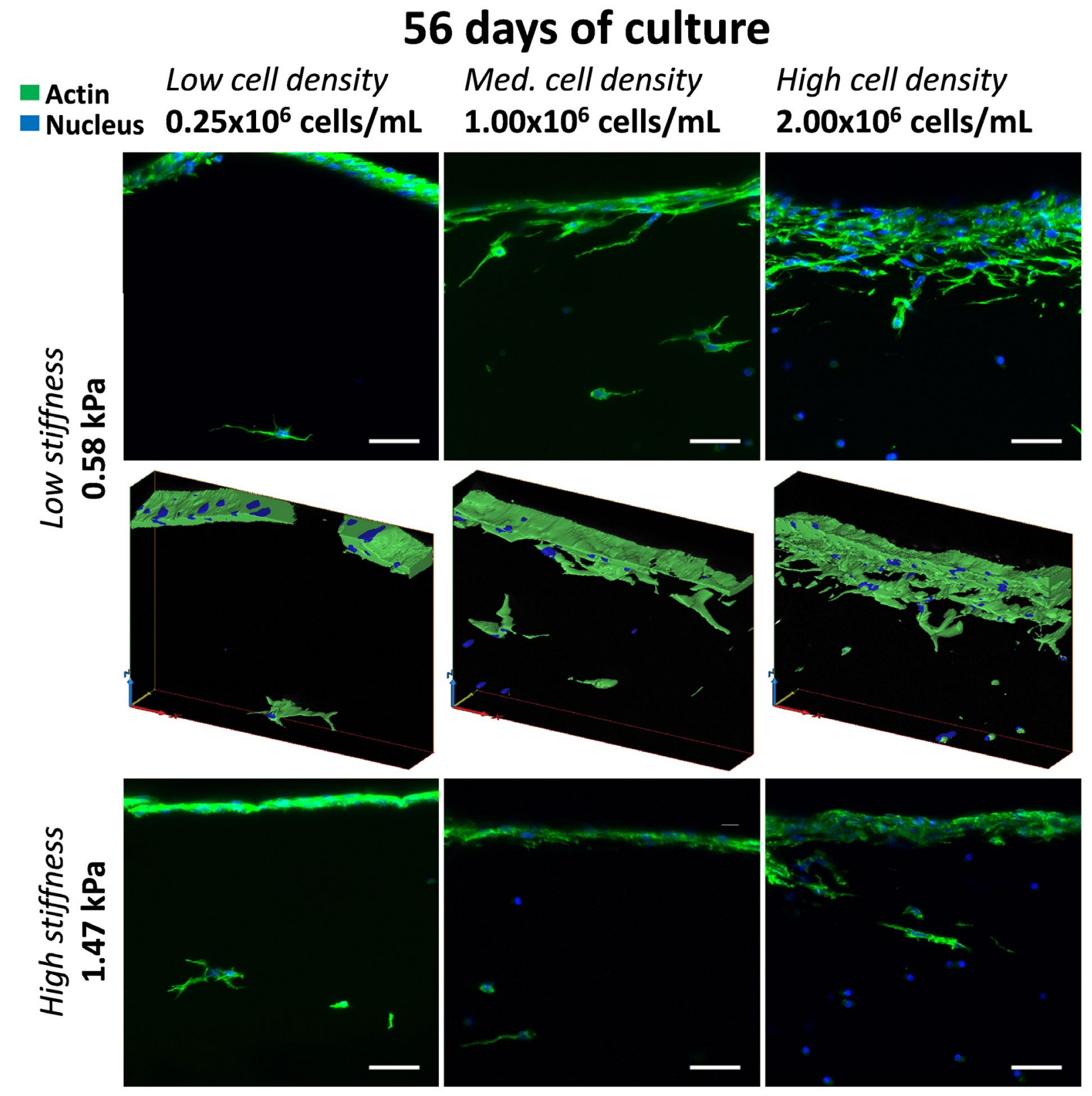

Fig. 6. Section views of cell morphologies and interconnections at $56 \mathrm{~d}$. Fluorescent images represented as 3D stacks in low stiffness matrix group. Scale bar $=50 \mu \mathrm{m}$.

cells. For the low cell density within a low stiffness matrix $6.9 \%$ of cells were interconnected, while $36.5 \%$ were unconnected and $56.6 \%$ connected as dividing cells. For the higher stiffness matrix at the same cell density $4.6 \%$ of cells were interconnected, $89.1 \%$ were unconnected and $6.3 \%$ connected as dividing cells, see Fig. 8D.

\section{Exploratory dendrites live cell imaging}

Cell dendrite formation was observed after $1 \mathrm{~h}$ of incubation within the lowest stiffness hydrogel. Dendrite formation was observed to increase with time. Dendrites were observed to be highly dynamic as cells repeatedly formed interconnections, extended and retracted their dendrites over the culture period. It was also observed that individual cells were active and viable throughout the entire $56 \mathrm{~d}$ culture period without proliferating, see Fig. 9A, 9B.
However, it was also observed that an individual cell that initially exhibited a dendritic morphology, could became balled up, reduce in size and remain in the hydrogel for the 56 day culture period (Fig. 9A, black arrows). These cells were referred to as "dormant" due to showing no normal cell activity (dendritic, motile, change in cell morphology, etc.) throughout the culture period.

\section{DMP-1 immunofluorescent staining}

Immunofluorescent staining for DMP-1 showed positive expression of DMP-1 within the proximity of cells encapsulated within the soft stiffness matrix $(0.58 \mathrm{kPa})$, see Fig. 10. At $10 \times$ magnification, DMP-1 staining was observed within the proximity of dendritic and interconnected cells at a medium cell density, see Fig. 10B. At $40 \times$ magnification, at a low and high cell density, DMP- 


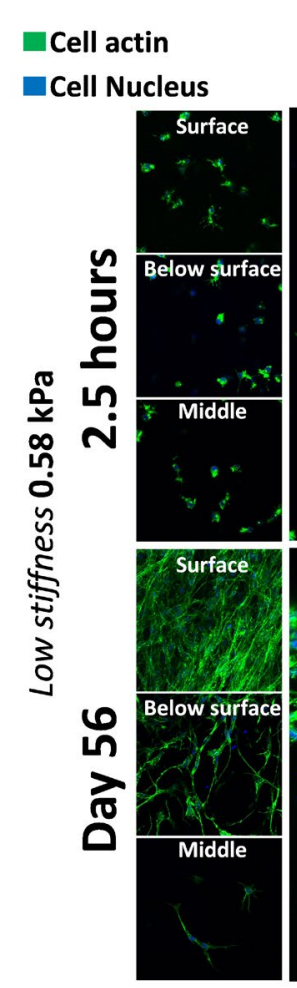

Plan View
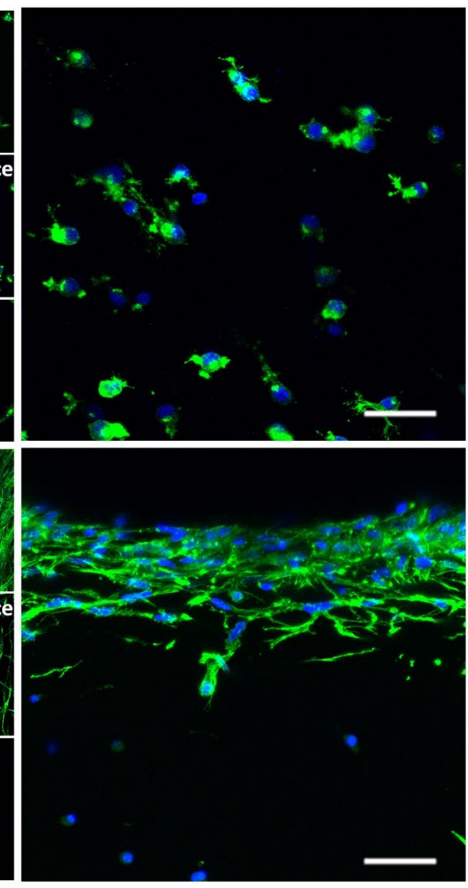

Section view
High cell density

$2.00 \times 10^{6}$ cells $/ \mathrm{mL}$
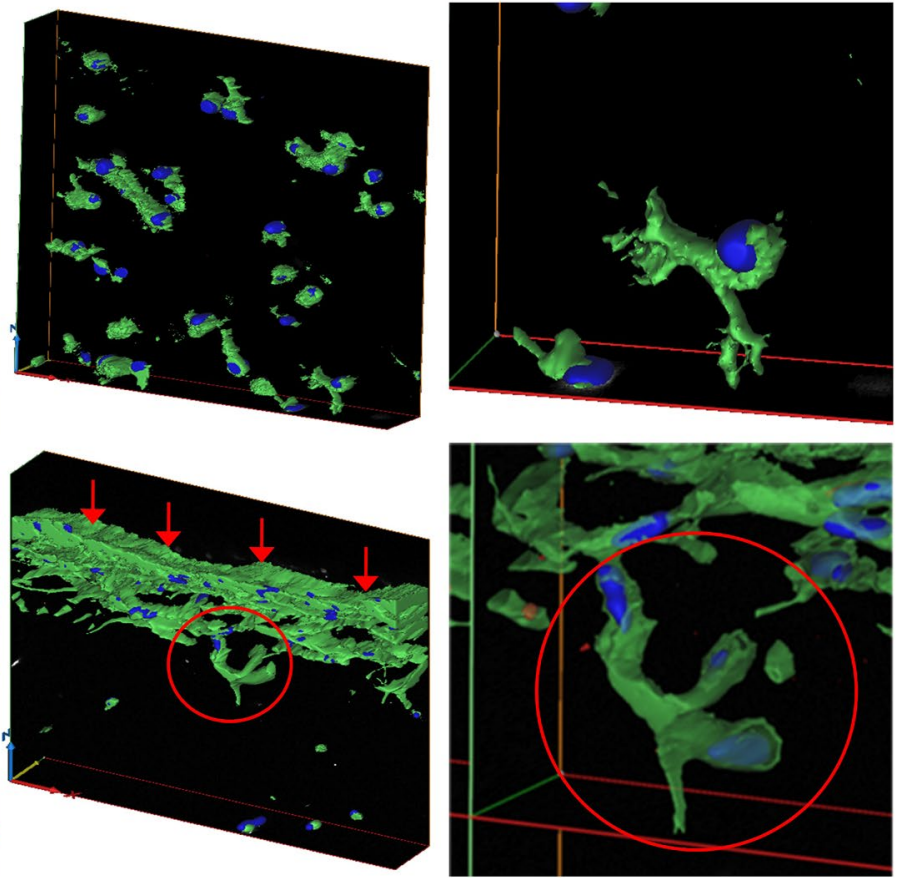

3D interconnected osteocytes

Fig. 7. Section view images of low stiffness matrix and high cell density comparing cell morphologies and interconnections at $2.5 \mathrm{~h}$ and $56 \mathrm{~d}$. After $2.5 \mathrm{~h}$, cells form dendrites throughout the hydrogel. By $56 \mathrm{~d}$, cells proliferate on surface, exhibiting a spread and confluent morphology (red arrows), progressing from the hydrogel surface cells become dendritic and forming interconnections (red circle). Scale bar $=50 \mu \mathrm{m}$.

1 staining was observed within matrices at day 21 and 56 (Fig. 10C-F). DMP-1 staining, at the high cell density was observed as dispersed nodules within the surrounding matrix of dendritic and interconnected cells (blue arrows) (Fig. 10E, 10F). DMP-1 staining was not observed in the negative control, where the primary antibody was omitted (Fig. 10A).

\section{ALP activity of cells}

Extracellular alkaline phosphatase activity by day 3 showed a significant increase for the low cell density group within both the low and high stiffness matrices compared to all other groups at the same time-point $(p<0.0001)$. Furthermore, at a low cell density a significant increase in ALP activity was also observed in the high stiffness matrix compared to the low stiffness matrices $(15.18 \pm 2.1 \mathrm{nmol} /$ $\mu \mathrm{g} v s .12 .31 \pm 1.22 \mathrm{nmol} / \mu \mathrm{g}, p<0.0002)$. Similarly, by day 21 significantly higher ALP activity was observed within the low cell density groups for both the low and high stiffness matrices compared to the other groups at the same time-point $(p<0.0002)$. By day 56, ALP activity was downregulated in all groups with no significant difference between groups, see Fig. 11.

\section{Mineralisation}

Calcium content in the high cell density group within a low and high stiffness matrix showed a significant increase in mineralisation from day 21 to $56(p<0.05)$. By day 56 , significantly higher calcium content was observed in the high cell density group within both the low and high stiffness matrix compared to the other groups at the same time-point $(p<0.05)$. Furthermore, a significant difference $(p<0.0287)$ in calcium content was observed between the low and high matrix stiffness $(29.23 \pm 7.38 \mu \mathrm{g}$ $20.3 \pm 10.06 \mu \mathrm{g})$, see Fig. 12 .

\section{Discussion}

The results of this study show for the first time that osteocyte differentiation of MC3T3-E1 cells is regulated within a 3D cell environment by ECM stiffness and cell density. Specifically, we showed that the highest extent of osteoblast-osteocyte differentiation occurred within a soft $3 \mathrm{D}$ matrix $(0.58 \mathrm{kPa})$ at high cell density $\left(2 \times 10^{6}\right.$ cells $\left./ \mathrm{mL}\right)$. Interestingly, after $56 \mathrm{~d}$ of culture these conditions led to the formation of an osteocyte-like network within the 3D matrix, characterised by long dendrites interconnecting with neighbouring osteocytic cells. DMP-1, a secreted protein that is upregulated during osteoblast to osteocyte differentiation, was identified within the matrix by immunohistochemistry. At the surface of this matrix cells formed a confluent layer, characteristic of osteoblast-like cells, which was also interconnected with the osteocytelike network. Bone has a similar structure in vivo, wherein osteocytes form a complex interconnected network allowing for communicating with their neighbours and with osteoblasts cells on bone surfaces via long cellular 
Actin Nucleus

A

56 days of culture
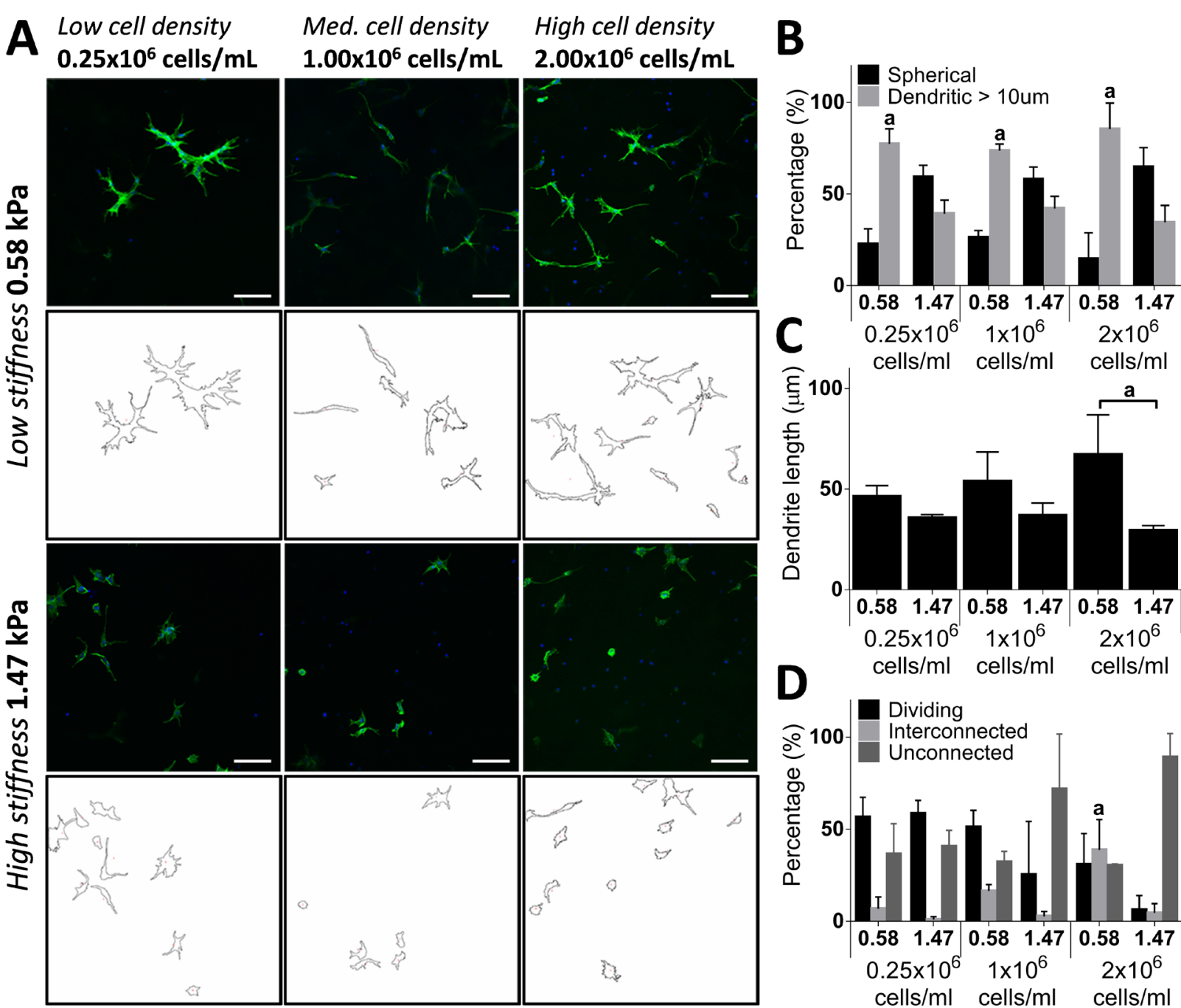

Fig. 8. Actin staining and particle analysis illustrations of cell morphology after $56 \mathrm{~d}$ of culture comparing spherical vs. dendritic morphology (A) within low $(0.58 \mathrm{kPa})$ and high $(1.47 \mathrm{kPa})$ stiffness matrices. Also shown is the percentage of spherical vs. dendritic cells $(\mathbf{B})$, average cell dendrite length $(\mathbf{C})$ and percentage of interconnections formed between cells $(\mathbf{D}) .{ }^{\mathrm{a}} p<0.05$ representing a statistical difference between low $(0.58 \mathrm{kPa})$ and high $(1.47 \mathrm{kPa})$ stiffness at the same density group. Scale bar $=100 \mu \mathrm{m}$.

processes. Within a stiffer matrix $(1.47 \mathrm{kPa})$ at a low cell density, dendrite formation occurred but these dendrites were shorter and a reduced interconnecting network was established. These findings reveal that both the mechanical properties of ECM and the ability for cells to establish a communication network within a $3 \mathrm{D}$ environment, play a significant role in osteocyte differentiation and the formation an interconnected network.

Cell migration, proliferation and differentiation have all been shown to be influenced by substrate (2D) or matrix (3D) stiffness (Engler et al., 2004; Hadjipanayi et al., 2009; Lo et al., 2000; Mullen et al., 2013; Tan et al., 2014; Zaman and Trapani, 2006). In particular, a soft 2D substrate $(0.3 \mathrm{kPa})$ was shown to lead to osteocyte differentiation (Mullen et al., 2013), whereas more rigid 2D substrates (40 kPa) favour osteoblast differentiation (Engler et al.,
2004). Osteoblast to osteocyte differentiation has been previously elicited in human primary osteoblast-like cells within 3D collagen gels, with $10 \%$ of cells becoming dendritic and expressing osteocyte-specific gene E11 after 28 d (Atkins et al., 2009). Primary mouse calvarial and MC3T3-E1 cells formed dendrites and expressed osteocyte-specific genes (DMP1, Sost, Phex) after 35 d on type I collagen gels with osteogenic supplements ( $\beta$-glycerophosphate and ascorbic acid) (Uchihashi et al., 2013). The mouse clonal cell line (IDG-SW3) developed dendrites and expressed osteocytic markers (DMP1, Sost) after $30 \mathrm{~d}$ on 3D collagen sponges (Woo et al., 2011). Osteoblast-osteocyte differentiation, has been induced in human osteoblasts cultured in 3D with hydroxyapatite/ tricalcium phosphate biphasic calcium phosphate ceramic particles (Boukhechba and Balaguer, 2009). However, these 

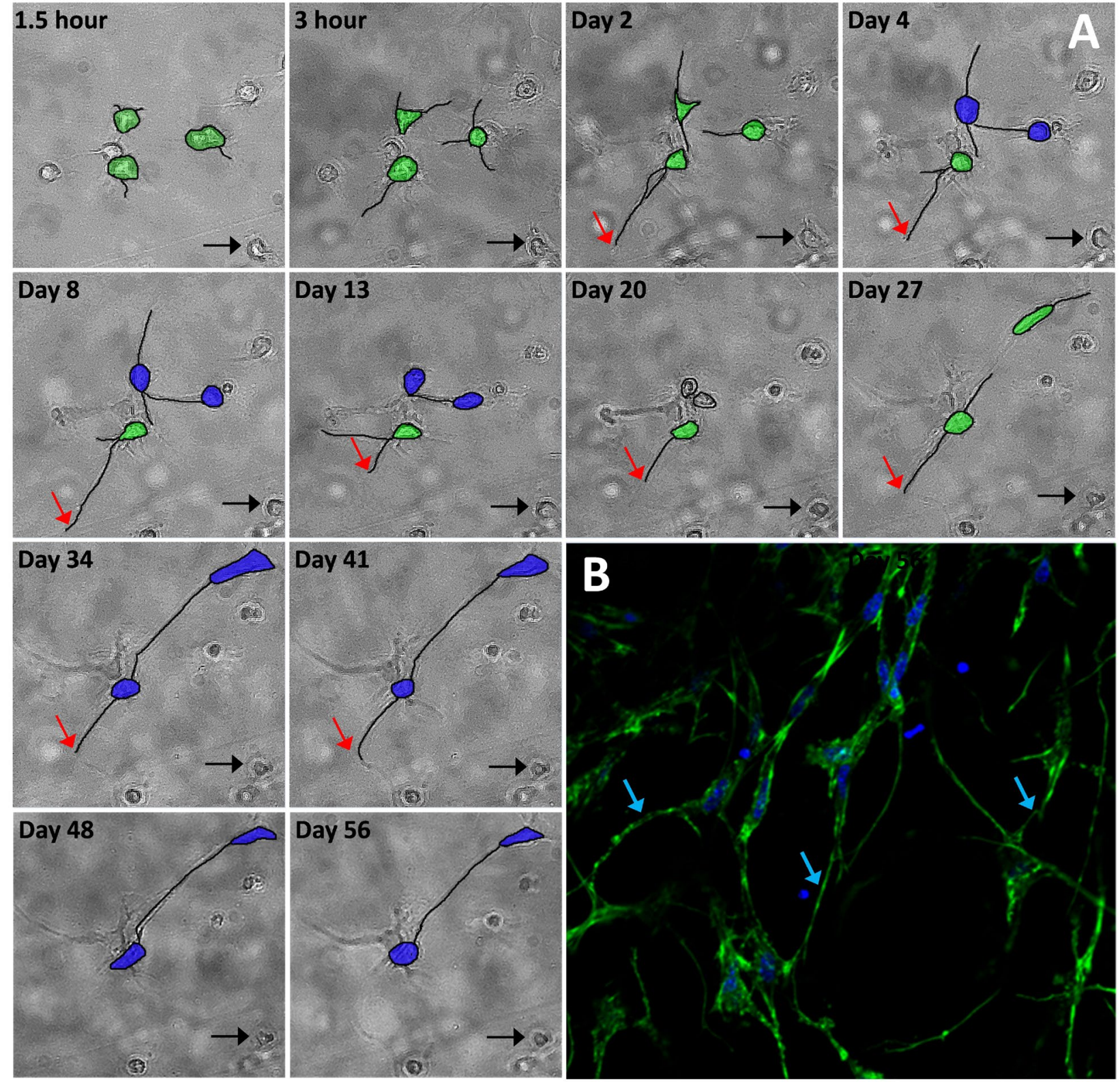

Fig. 9. (A) Live cell imaging of a low stiffness matrix at a high cell density show cells (green cells) to be highly dynamic and constantly sending out exploratory dendrites (red arrow) throughout the study, while at the later timepoints the same cells formed interconnections with neighbouring cells (blue cells). Furthermore, cells that became balled up and encapsulated (Black arrows), were observed to remain balled up within the hydrogel throughout the $56 \mathrm{~d}$ culture period and were classified as dormant. (B) Fluorescent imaging at day 56 show interconnections formed between cells (blue arrow).

studies did not characterise the mechanical properties of the 3D matrix and could not uncover the role of the mechanical environment for eliciting osteocyte differentiation. The hydrogel stiffness used here $(0.58 / 1.47 \mathrm{kPa})$ are within the range of gelatin-mtgase hydrogels $(1.58 / 32.32 \mathrm{kPa})$ used to elicit differentiaton of mouse myoblast cells towards osteoblasts (Tan et al., 2014), which showed osteoblast-like cells became elongated at stiffnesses of $1.58 \mathrm{kPa}$, but were spherical at higher stiffnesses (32.32 kPa) (Tan et al., 2014). In the current study we show for the first time that osteocyte differentiation and the formation of interconnections is governed by soft $3 \mathrm{D}$ matrices $(0.58 \mathrm{kPa})$. In contrast to previous studies, these results were achieved without addition of osteogenic growth factors.

In vivo, osteocytes are formed when osteoblasts become embedded within soft secreted osteoid and undergo a dramatic phenotypic transition to a dendritic shape (Knothe Tate et al., 2004; Palumbo et al., 2004), secrete DMP-1 protein, and form interconnections with neighbouring and surface cells to establish the osteocyte network. Interestingly, we observed the same traits of a dramatic phenotypic transition to a dendritic shape, DMP1 expression and formation of an osteocyte network in cells cultured within a soft matrix. We propose that the 


\section{Actin}

Nucleus Med. cell density

DMP-1

\section{$1.00 \times 10^{6}$ cells $/ \mathrm{mL}$}
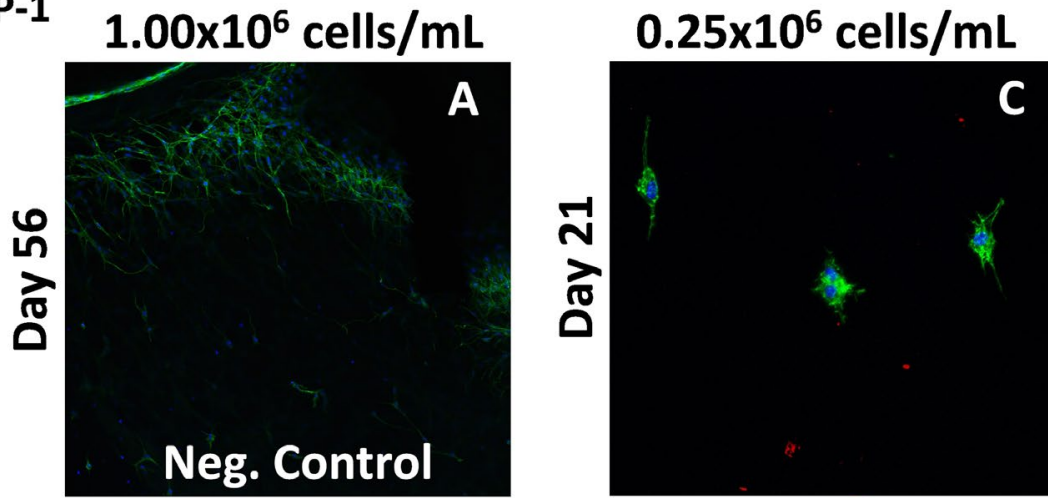

High cell density
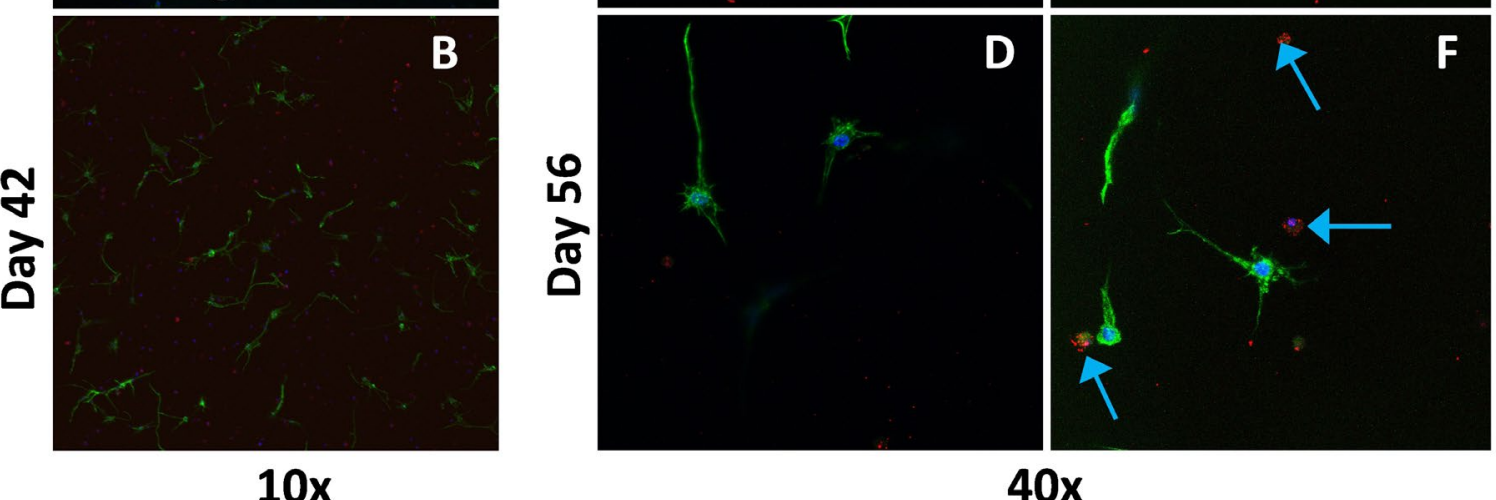

$10 x$

$40 x$

Fig. 10. Immunofluorescent images of DMP-1 from cells encapsulated in a hydrogel at a low matrix stiffness $(0.58 \mathrm{kPa})$. (A) Negative controls were performed by omitting the primary antibody and no DMP-1 staining was observed. (B) DMP-1 staining was observed within the proximity of dendritic and interconnected cells at a medium cell density $(10 \times$ magnification $)$. At a low $(\mathbf{C}, \mathbf{D})$ and high $(\mathbf{E}, \mathbf{F})$ cell density, DMP-1 staining was observed within matrices at day 21 and $56(40 \times$ magnification). DMP-1 staining, at the high cell density $(\mathbf{E}, \mathbf{F})$ was observed as dispersed nodules within the surrounding matrix of dendritic and interconnected cells (Blue arrows, $40 \times$ magnification). Images were taken at approximately $50 \mu \mathrm{m}$ below the hydrogel surface. Scale bar for $10 \times(\mathbf{A}, \mathbf{B})$ $=120 \mu \mathrm{m} ; 40 \times(\mathbf{C}, \mathbf{D}, \mathbf{E}, \mathbf{F})=50 \mu \mathrm{m}$.

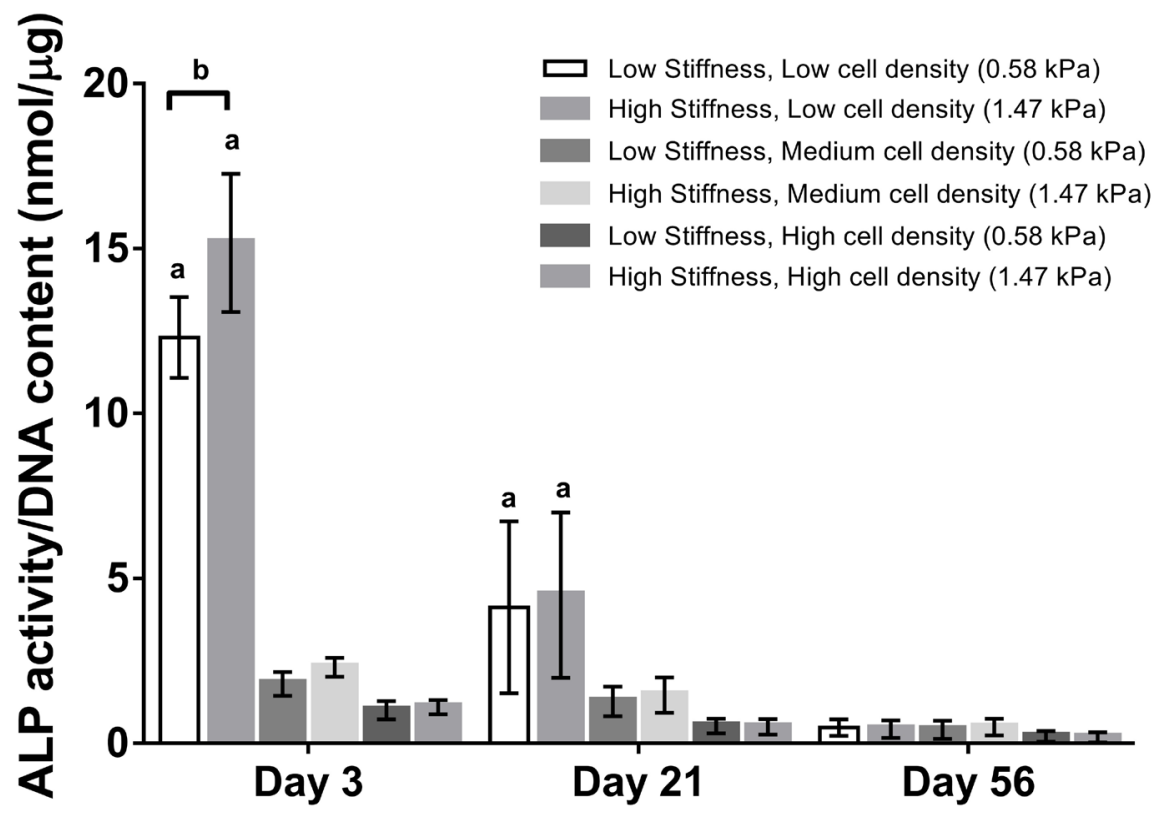

Fig. 11. Extracellular ALP activity of each group at day 3, 21 and 56 ( $n=6$ samples per group per time-point). ${ }^{a} p<0.05$ relative to the other cell density groups at the same time-point and ${ }^{\mathrm{b}} p<0.05$ representing a statistical difference between low and high stiffness. Error bars denote standard deviation. 


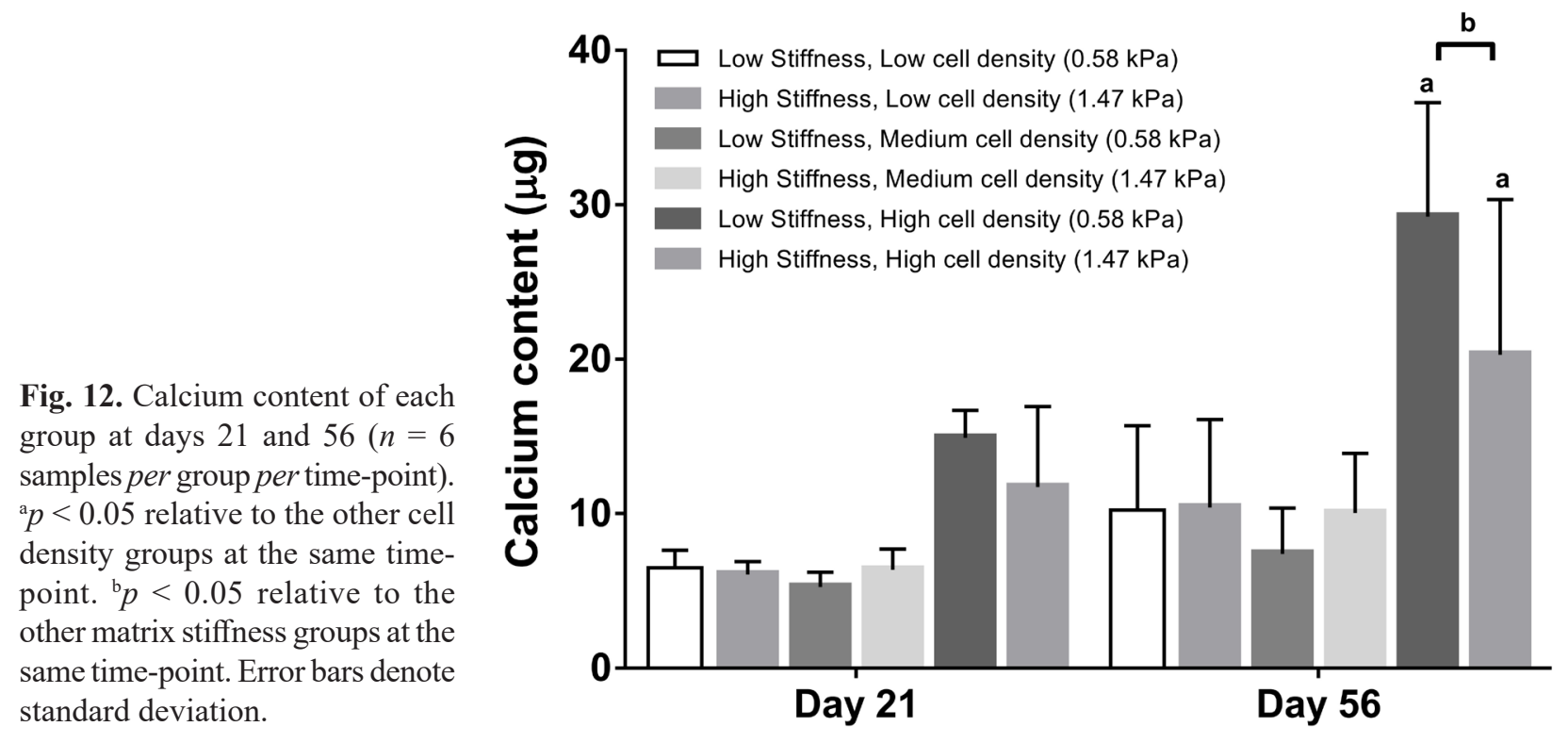

mechanical properties of the hydrogel matrix might provide similar extracellular mechanical cues to that of osteoid, which is a crucial component required for the embedding of an osteoblast and stimulating osteocyte differentiation in vivo.

Previous in vitro studies have shown the significance of cell density on osteogenic cell differentiation. Rat bone marrow stromal cells (BMSC) grown at low density $\left(7.5 \times 10^{4}\right.$ cells $\left./ \mathrm{cm}^{2}\right)$ for $8 \mathrm{~d}$ on $2 \mathrm{D}$ poly(propylene fumarate), expressed higher amounts of ALP activity compared to cells at a high density $\left(14.9 \times 10^{4}\right.$ cells $/$ $\mathrm{cm}^{2}$ ) (Kim et al., 2009). We previously reported that MC3T3-E1 cells cultured at low density $\left(0.1 \times 10^{4}\right.$ cells/ $\mathrm{cm}^{2}$ ) had higher ALP activity compared to those at high density $\left(1 \times 10^{4}\right.$ cells $\left./ \mathrm{cm}^{2}\right)$, albeit that higher amounts of mineralisation were reported for the low seeding density (Mullen et al., 2013). Human marrow-derived MSC cells and MG-63 osteosarcoma cells encapsulated at low densities $\left(2 \times 10^{6} / 3 \times 10^{6}\right.$ cells $\left./ \mathrm{mL}\right)$ within $3 \mathrm{D}$ collagen/ alginate gels had higher ALP activity than cells seeded at higher densities $\left(1 \times 10^{8} / 15 \times 10^{6}\right.$ cells $\left./ \mathrm{mL}\right)($ Bitar et al., 2008; Maia et al., 2014). Here we showed that a low density $\left(0.4 \times 10^{4}\right.$ cells $/ \mathrm{cm}^{2} \sim 0.25 \times 10^{6}$ cells $\left./ \mathrm{mL}\right)$ lead to higher ALP production after $3 \mathrm{~d}$, compared to cells seeded at a high density $\left(1.6 \times 10^{4}\right.$ cells $/ \mathrm{cm}^{2} \sim 2 \times 10^{6}$ cells $\left./ \mathrm{mL}\right)$. Furthermore, we observed an increase in calcium content in the high cell density $\left(1.6 \times 10^{4}\right.$ cells $/ \mathrm{cm}^{2} \sim 2 \times 10^{6}$ cells/ $\mathrm{mL}$ ) group within a low and high stiffness matrix compared to the other groups by $56 \mathrm{~d}$.

The osteocyte network is analogous to the neuronal network, whereby neurons extend long interconnected dendrites. Studies have shown an increase in the percentage of neurons on 2D substrates $(0.25-7 \mathrm{kPa})$ (Georges et al., 2006; Previtera et al., 2010), while in soft 3D agarose gels $(\sim 0.002 \mathrm{kPa})$ increased elongation rates of neurites relative to stiff gels $(\sim 0.13 \mathrm{kPa})$ have been observed (Balgude $e t$ al., 2001). Interestingly, DMP-1 expression has also been observed within the brain, suggesting strong ties with dendrite formation in neuron cells (Kalajzic et al., 2004).
Therefore, we propose that the formation of a dendritic interconnected network within both neurons and osteocytes is driven by ECM stiffness and cell density.

Our results show that cells within a soft $3 \mathrm{D}$ matrix are dispersed throughout long-term culture and form interconnections with neighbouring cells (Fig. 4A \& Fig. $5 \mathbf{A}$ ), whereas those near the surface proliferate and form a confluent layer on the surface of the hydrogel, see Fig. 7. Similarly, HepG2 cells proliferate more when grown on 2D collagen substrates than when encapsulated within a 3D alginate gels (Lan et al., 2010). It is intriguing to speculate on the potential mechanisms by which embedded cells form dendrites and interconnected networks inside gelatin hydrogels. Our live cell results (Fig. 9A) and other studies (Balgude et al., 2001; Dallas et al., 2013; Dallas and Bonewald, 2010; Shahar and Dean, 2013; Webster et al., 2013) have shown that osteocytes and neurites are highly dynamic and repeatedly extend and retract their dendrites, and can establish connections with neighbouring cells through gap junctions (Doty, 1981; Palumbo et al., 2004) to form interconnected networks. Osteocyte dendrite formation is highly dependent on continuous cleavage of collagen through enzymes known as matrix metalloproteinases (MMPs) (Holmbeck et al., 2005), which are expressed by osteocytes (Hatori et al., 2004). Interestingly, matrix degradation through MMP activity has been shown in gelatin gels (d'Ortho et al., 1998). Therefore, we propose that osteoblastic cells encapsulated with softer matrices form dendrites and express MMPs to degrade the matrix macromolecules, allowing for the dendrite to perforate through the matrix. The higher degree of crosslinking between matrix macromolecules in the high stiffness group might present a matrix that is more difficult to degrade and thus explain the lower proportion of dendritic cells in these matrices.

The use of osteoblast-like MC3T3-E1 cell-line is a possible limitation of this study. However, isolating primary osteoblasts can produce inhomogeneous cell populations and osteoblast-specific features can be lost 
upon subcultivation (Leis et al., 1997; Quarles et al., 1992). The MC3T3-E1 osteoblast cell line represents a uniformly defined cell population, which have similar traits to primary cells and can be readily expanded (Czekanska et al., 2012) and differentiated (Chatterjee et al., 2010; Keogh et al., 2010; Krishnan et al., 2010; Mullen et al., 2013; Partap et al., 2010; Przybylowski et al., 2012; St-Pierre et al., 2005; Uchihashi et al., 2013), making the cell line a good representative of pre-osteoblasts (Grigoriadis et al., 1985; Quarles et al., 1992; Sudo et al., 1983; Wang et al., 1999). It should be noted that ALP activity was only assessed from extracellular ALP in the media at specific time-points and thus might not be a reflection of the total ALP activity. Finally, we did not investigate precisely the mechanical environment that arises during osteocyte differentiation in vivo or the mechanical environment known to elicit osteoblast-osteocyte differentiation in $2 \mathrm{D}(\sim 0.3 \mathrm{kPa})$ (Mullen et al., 2013). However, the mechanical properties of osteoid are unknown, as newly laid down osteoid tissue represents a thin layer approximately $350 \mathrm{~nm}$ deep, which has made the extraction of samples for mechanical testing unfeasible. Moreover, maintaining a homogeneous cell distribution in a low stiffness $3 \mathrm{D}$ matrix $(\sim 0.3 \mathrm{kPa})$ proved challenging as the cells settled at the bottom of the well before gelling occurred, whereas $0.58 \mathrm{kPa}$ was found to be the lowest achievable matrix stiffness to avoid settling from occurring. Nonetheless the results of this study showed that osteocyte differentiation of MC3T3-E1 cells was indeed regulated within a $3 \mathrm{D}$ cell environment by ECM stiffness and cell density.

Various in vitro bone TE approaches, including porous biomaterial scaffolds (Correia et al., 2012; Curtin et al., 2012; Gleeson et al., 2010; Keogh et al., 2010), cellular aggregates (Freeman et al., 2015; Fuchs et al., 2007; Rouwkema et al., 2006) and cell encapsulation within hydrogels (Castillo Diaz et al., 2014; Chatterjee et al., 2010; Shin et al., 2014; Tan et al., 2014), have shown potential for bone regeneration, as indicated by osteogenic protein and mineral production. However, none of these have reported substantial osteocyte differentiation, dendrite formation or interconnected osteocyte networks within the constructs. The approach developed here may be a promising tool to reproduce bone constructs with an osteocyte network in place, which is an essential component in the formation of bone and the treatment of large bone defects.

\section{Conclusion}

The results of this study show that external biophysical and biochemical cues, such as matrix stiffness and cell density, control the phenotypic shift from osteoblasts to osteocytes in a $3 \mathrm{D}$ environment. For the first time MC3T3 - E1 osteoblast cells, at a seeding density of $2 \times 10^{6}$ cells $/ \mathrm{mL}$ within a soft $3 \mathrm{D}$ matrix $(0.58 \mathrm{kPa})$, have been induced to undergo osteocyte differentiation and form an interconnected network by $56 \mathrm{~d}$ of culture. On the matrix surface a confluent layer, representative of osteoblastic differentiation, was established. These results were achieved without the addition of growth factors. We propose that the encapsulation of cells within a soft matrix simulates the in vivo environment, wherein osteoblasts start to differentiate towards osteocytes after they have become embedded within osteoid, a soft unmineralised bone matrix. Future TE approaches could apply this method to develop bone constructs with an osteocyte network in place.

\section{Acknowledgements}

This project was supported by the European Research Council Grant 258992 (BONEMECHBIO). The authors acknowledge the facilities and scientific and technical assistance of the Centre for Microscopy \& Imaging at the National University of Ireland Galway (www.imaging. nuigalway.ie), a facility that is funded by NUIG and the Irish Government's Programme for Research in Third Level Institutions, Cycles 4 and 5, National Development Plan 2007-2013.

\section{References}

Anderson EJ, Knothe Tate ML (2008) Idealization of pericellular fluid space geometry and dimension results in a profound underprediction of nano-microscale stresses imparted by fluid drag on osteocytes. J Biomech 41: 17361746.

Atkins GJ, Welldon KJ, Wijenayaka AR, Bonewald LF, Findlay DM (2009) Vitamin K promotes mineralization, osteoblast-to-osteocyte transition, and an anticatabolic phenotype by $\{$ gamma $\}$-carboxylation-dependent and -independent mechanisms. Am J Physiol Cell Physiol 297: C1358-C1367.

Balgude AP, Yu X, Szymanski A, Bellamkonda RV (2001) Agarose gel stiffness determines rate of DRG neurite extension in 3D cultures. Biomaterials 22: 1077 1084.

Barragan-Adjemian C, Nicolella D, Dusevich V, Dallas MR, Eick JD, Bonewald LF (2006) Mechanism by which MLO-A5 late osteoblasts/early osteocytes mineralize in culture: similarities with mineralization of lamellar bone. Calcif Tissue Int 79: 340-353.

Bitar M, Brown RA, Salih V, Kidane AG, Knowles JC, Nazhat SN (2008) Effect of cell density on osteoblastic differentiation and matrix degradation of biomimetic dense collagen scaffolds. Biomacromolecules 9: 129-135.

Boukhechba F, Balaguer T, Michiels JF, Ackermann K, Quincey D, Bouler JM, Pyerin W, Carle GF, Rochet N (2009) Human primary osteocyte differentiation in a 3D culture system. J Bone Miner Res 24: 1927-1935.

Burger EH, Klein-Nulend J (1999) Mechanotransduction in bone-role of the lacuno-canalicular network. FASEB J 13: S101-S112.

Castillo Diaz LA, Saiani A, Gough JE, Miller AF (2014) Human osteoblasts within soft peptide hydrogels promote mineralisation in vitro. J Tissue Eng 5: doi: 10.1177/2041731414539344.

Chatterjee K, Lin-Gibson S, Wallace WE, Parekh SH, Lee YJ, Cicerone MT, Young MF, Simon CG JR (2010) The effect of 3D hydrogel scaffold modulus on 
osteoblast differentiation and mineralization revealed by combinatorial screening. Biomaterials 31: 5051-5062.

Correia C, Bhumiratana S, Yan LP, Oliveira AL, Gimble JM, Rockwood D, Kaplan DL, Sousa RA, Reis RL, Vunjak-Novakovic G (2012) Development of silkbased scaffolds for tissue engineering of bone from human adipose-derived stem cells. Acta Biomater 8: 2483-2492.

Curtin CM, Cunniffe GM, Lyons FG, Bessho K, Dickson GR, Duffy GP, O’Brien FJ (2012) Innovative collagen nano-hydroxyapatite scaffolds offer a highly efficient non-viral gene delivery platform for stem cellmediated bone formation. Adv Mater 24: 749-754.

Czekanska EM, Stoddart MJ, Richards RG, Hayes JS (2012) In search of an osteoblast cell model for in vitro research. Eur Cell Mater 24: 1-17.

d'Ortho MP, Stanton H, Butler M, Atkinson SJ, Murphy G, Hembry RM (1998) MT1-MMP on the cell surface causes focal degradation of gelatin films. FEBS Lett 421: 159-164.

D'Souza RN, Cavender A, Sunavala G, Alvarez J, Ohshima T, Kulkarni AB, MacDougall M (1997) Gene expression patterns of murine dentin matrix protein 1 (Dmp1) and dentin sialophosphoprotein (DSPP) suggest distinct developmental functions in vivo. J Bone Miner Res 12: 2040-2049.

Dallas SL, Bonewald LF (2010) Dynamics of the transition from osteoblast to osteocyte. Ann N Y Acad Sci 1192: 437-443.

Dallas SL, Prideaux M, Bonewald LF (2013) The osteocyte: an endocrine cell and more. Endocr Rev 34: 658-690.

Doty SB (1981) Morphological evidence of gap junctions between bone cells. Calcif Tissue Int 33: 509-512.

Engler A, Bacakova L, Newman C, Hategan A, Griffin M, Discher D (2004) Substrate compliance versus ligand density in cell on gel responses. Biophys J 86: 617-628.

Engler AJ, Sen S, Sweeney HL, Discher DE (2006) Matrix elasticity directs stem cell lineage specification. Cell 126: 677-689.

Evans ND, Minelli C, Gentleman E, LaPointe V, Patankar SN, Kallivretaki M, Chen X, Roberts CJ, Stevens MM (2009) Substrate stiffness affects early differentiation events in embryonic stem cells. Eur Cell Mater 18: 1-13.

Feng JQ, Zhang J, Dallas SL, Lu Y, Chen S, Tan X, Owen M, Harris SE, MacDougall M (2002) Dentin matrix protein 1, a target molecule for Cbfa1 in bone, is a unique bone marker gene. J Bone Miner Res 17: 1822-1831.

Freeman FE, Haugh MG, McNamara LM (2015) An in vitro bone tissue regeneration strategy combining chondrogenic and vascular priming enhances the mineralization potential of mesenchymal stem cells in vitro while also allowing for vessel formation. Tissue Eng Part A 21: 1320-1332.

Fuchs S, Hofmann A, Kirkpatrick C (2007) Microvessel-like structures from outgrowth endothelial cells from human peripheral blood in 2-dimensional and 3-dimensional co-cultures with osteoblastic lineage cells. Tissue Eng 13: 2577-2588.

Georges PC, Miller WJ, Meaney DF, Sawyer ES, Janmey PA (2006) Matrices with compliance comparable to that of brain tissue select neuronal over glial growth in mixed cortical cultures. Biophys J 90: 3012-3018.

Gleeson JP, Plunkett NA, O’Brien FJ (2010) Addition of hydroxyapatite improves stiffness, interconnectivity and osteogenic potential of a highly porous collagen-based scaffold for bone tissue regeneration. Eur Cell Mater 20: 218-230.

Grigoriadis AE, Petkovich PM, Ber R, Aubin JE, Heersche JN (1985) Subclone heterogeneity in a clonallyderived osteoblast-like cell line. Bone 6: 249-256.

Hadjipanayi E, Mudera V, Brown RA (2009) Close dependence of fibroblast proliferation on collagen scaffold matrix stiffness. J Tissue Eng Regen Med 3: 77-84.

Han Y, Cowin SC, Schaffler MB, Weinbaum S (2004) Mechanotransduction and strain amplification in osteocyte cell processes. Proc Natl Acad Sci U S A 101: 1668916694.

Harley BA, Leung JH, Silva EC, Gibson LJ (2007) Mechanical characterization of collagenglycosaminoglycan scaffolds. Acta Biomater 3: 463-474.

Hatori K, Sasano Y, Takahashi I, Kamakura S, Kagayama M, Sasaki K (2004) Osteoblasts and osteocytes express MMP2 and -8 and TIMP1, -2 , and -3 along with extracellular matrix molecules during appositional bone formation. Anat Rec A Discov Mol Cell Evol Biol 277: 262-271.

Haugh MG, Murphy CM, McKiernan RC, Altenbuchner C, O’Brien FJ (2011) Crosslinking and mechanical properties significantly influence cell attachment, proliferation, and migration within collagen glycosaminoglycan scaffolds. Tissue Eng Part A 17: 12011208.

Holmbeck K, Bianco P, Pidoux I, Inoue S, Billinghurst RC, Wu W, Chrysovergis K, Yamada S, Birkedal-Hansen H, Poole AR (2005) The metalloproteinase MT1-MMP is required for normal development and maintenance of osteocyte processes in bone. J cell Sci 118: 147-156

Huebsch N, Arany PR, Mao AS, Shvartsman D, Ali OA, Bencherif SA, Rivera-Feliciano J, Mooney DJ (2010) Harnessing traction-mediated manipulation of the cell/ matrix interface to control stem-cell fate. Nat Mater 9: 518-526.

Jee WS (2001) Integrated Bone Tissue Physiology. In Bone Mech. Handbook, Second Ed., 1-68. CRC Press, March 15. doi:10.1201/b14263-3.

Kalajzic I, Braut A, Guo D, Jiang X, Kronenberg MS, Mina M, Harris MA, Harris SE, Rowe DW (2004) Dentin matrix protein 1 expression during osteoblastic differentiation, generation of an osteocyte GFP-transgene. Bone 35: 74-82.

Keogh MB, O’Brien FJ, Daly JS (2010) Substrate stiffness and contractile behaviour modulate the functional maturation of osteoblasts on a collagen-GAG scaffold. Acta Biomater 6: 4305-4313.

Kim K, Dean D, Mikos AG, Fisher JP (2009) Effect of initial cell seeding density on early osteogenic signal expression of rat bone marrow stromal cells cultured on cross-linked poly(propylene fumarate) disks. Biomacromolecules 10: 1810-1817.

Knothe Tate ML, Steck R, Forwood MR, Niederer P (2000) In vivo demonstration of load-induced fluid flow 
in the rat tibia and its potential implications for processes associated with functional adaptation. J Exp Biol 203: 2737-2745.

Knothe Tate ML, Niederer P, Knothe U (1998) In vivo tracer transport through the lacunocanalicular system of rat bone in an environment devoid of mechanical loading. Bone 22: 107-117.

Knothe Tate ML, Adamson JR, Tami AE, Bauer TW (2004) The osteocyte. Int J Biochem Cell Biol 36: 1-8.

Knothe Tate ML, Niederer P (1998) Theoretical FEbased model developed to predict the relative contribution of convective and diffusive transport mechanisms for the maintenance of local equilibria within cortical bone. In Pap. Present. ASME Heat Transfer Div Publ HTD 362: 133-141.

Krishnan V, Dhurjati R, Vogler EA, Mastro AM (2010) Osteogenesis in vitro: from pre-osteoblasts to osteocytes: a contributuion from the Osteobiology Research Group, The Pennsylvania State University. In Vitro Cell Dev Biol Anim 46: 28-35.

Lan SF, Safiejko-Mroczka B, Starly B (2010) Longterm cultivation of HepG2 liver cells encapsulated in alginate hydrogels: a study of cell viability, morphology and drug metabolism. Toxicol In Vitro 24: 1314-1323.

Lee JW, Yamaguchi A, Iimura T (2014) Functional heterogeneity of osteocytes in FGF23 production: the possible involvement of DMP1 as a direct negative regulator. Bonekey Rep 3: 543.

Legant WR, Miller JS, Blakely BL, Cohen DM, Genin GM, Chen CS (2010) Measurement of mechanical tractions exerted by cells in three-dimensional matrices. Nat Methods 7: 969-971.

Leis HJ, Hulla W, Gruber R, Huber E, Zach D, Gleispach H, Windischhofer W (1997) Phenotypic heterogeneity of osteoblast-like MC3T3-E1 cells: changes of bradykinin-induced prostaglandin E2 production during osteoblast maturation. J Bone Miner Res 12: 541-551.

Lo CM, Wang HB, Dembo M, Wang YL (2000) Cell movement is guided by the rigidity of the substrate. Biophys J 79: 144-152.

Maia FR, Lourenço AH, Granja PL, Gonçalves RM, Barrias CC (2014) Effect of cell density on mesenchymal stem cells aggregation in RGD-alginate 3D matrices under osteoinductive conditions. Macromol Biosci 14: 759-771.

McNamara LM, Majeska RJ, Weinbaum S, Friedrich V, Schaffler MB (2009) Attachment of osteocyte cell processes to the bone matrix. Anat Rec (Hoboken). 292: 355-363.

Mikuni-Takagaki Y, Kakai Y, Satoyoshi M, Kawano E, Suzuki Y, Kawase T, Saito S (1995) Matrix mineralization and the differentiation of osteocyte-like cells in culture. J Bone Miner Res 10: 231-242.

Mullen CA, Haugh MG, Schaffler MB, Majeska RJ, McNamara LM (2013) Osteocyte differentiation is regulated by extracellular matrix stiffness and intercellular separation. J Mech Behav Biomed Mater 28: 183-194.

Mullen CA, Vaughan TJ, Voisin MC, Brennan MA, Layrolle P, McNamara LM (2014) Cell morphology and focal adhesion location alters internal cell stress. J R Soc Interface 11:. doi: 10.1098/rsif.2014.0885.
Murshid SA, Kamioka H, Ishihara Y, Ando R, Sugawara Y, Takano-Yamamoto T (2007) Actin and microtubule cytoskeletons of the processes of 3D-cultured MC3T3-E1 cells and osteocytes. J Bone Miner Metab 25: 151-158.

Nakano Y, Beertsen W, Van Den Bos T, Kawamoto T, Oda K, Takano Y (2004) Site-specific localization of two distinct phosphatases along the osteoblast plasma membrane: tissue non-specific alkaline phosphatase and plasma membrane calcium ATPase. Bone 35: 1077-1085.

Narayanan K, Ramachandran A, Hao J, He G, Park KW, Cho M, George A (2003) Dual functional roles of dentin matrix protein 1. Implications in biomineralization and gene transcription by activation of intracellular $\mathrm{Ca} 2+$ store. J Biol Chem 278: 17500-17508.

Palazzini S, Palumbo C, Ferretti M, Marotti G (1998) Stromal cell structure and relationships in perimedullary spaces of chick embryo shaft bones. Anat Embryol (Berl) 197: 349-357.

Palumbo C (1986) A three-dimensional ultrastructural study of osteoid-osteocytes in the tibia of chick embryos. Cell Tissue Res 246: 125-131.

Palumbo C, Ferretti M, Marotti G (2004) Osteocyte dendrogenesis in static and dynamic bone formation: an ultrastructural study. Anat Rec A Discov Mol Cell Evol Biol 278: 474-480.

Partap S, Plunkett NA, Kelly DJ, O’Brien FJ (2010) Stimulation of osteoblasts using rest periods during bioreactor culture on collagen-glycosaminoglycan scaffolds. J Mater Sci Mater Med 21: 2325-2330.

Previtera ML, Langhammer CG, Firestein BL (2010) Effects of substrate stiffness and cell density on primary hippocampal cultures. J Biosci Bioeng 110: 459-470.

Prideaux M, Loveridge N, Pitsillides AA, Farquharson C (2012) Extracellular matrix mineralization promotes E11/gp38 glycoprotein expression and drives osteocytic differentiation. PLoS One 7: e36786.

Przybylowski C, Quinn T, Callahan A, Kaplan M, Golding A, Alesi C, Ammar M, LeBlon CE, Guo Y, Zhang X, Jedlicka SS (2012) MC3T3 preosteoblast differentiation on bone morphogenetic protein-2 peptide ormosils. J Mater Chem 22: 10672-10683.

Quarles LD, Yohay DA, Lever LW, Caton R, Wenstrup RJ (1992) Distinct proliferative and differentiated stages of murine MC3T3-E1 cells in culture: an in vitro model of osteoblast development. J Bone Miner Res 7: 683-692.

Rios HF, Ye L, Dusevich V, Eick D, Bonewald LF, Feng JQ (2005) DMP1 is essential for osteocyte formation and function. J Musculoskelet Neuronal Interact 5: 325-327.

Rouwkema J, de Boer J, Van Blitterswijk CA (2006) Endothelial cells assemble into a 3-dimensional prevascular network in a bone tissue engineering construct. Tissue Eng 12: $2685-2693$.

Shahar R, Dean MN (2013) The enigmas of bone without osteocytes. Bonekey Rep 2: 343.

Shin H, Olsen BD, Khademhosseini A (2014) Gellan gum microgel-reinforced cell-laden gelatin hydrogels. J Mater Chem B Mater Biol Med 2: 2508-2516.

Soares CP, Midlej V, de Oliveira ME, Benchimol M, Costa ML, Mermelstein C (2012) 2D and 3D-organized cardiac cells shows differences in cellular morphology, adhesion junctions, presence of myofibrils and protein 
expression. PLoS One 7: doi:10.1371/journal. pone.0038147.

St-Pierre JP, Gauthier M, Lefebvre L-P, Tabrizian M (2005) Three-dimensional growth of differentiating MC3T3-E1 pre-osteoblasts on porous titanium scaffolds. Biomaterials 26: 7319-7328.

Sudo H, Kodama HA, Amagai Y, Yamamoto S, Kasai $\mathrm{S}$ (1983) In vitro differentiation and calcification in a new clonal osteogenic cell line derived from newborn mouse calvaria. J Cell Biol 96: 191-198.

Tan S, Fang JY, Yang Z, Nimni ME, Han B (2014) The synergetic effect of hydrogel stiffness and growth factor on osteogenic differentiation. Biomaterials 35: 5294-5306.

Uchihashi K, Aoki S, Matsunobu A, Toda S (2013) Osteoblast migration into type I collagen gel and differentiation to osteocyte-like cells within a selfproduced mineralized matrix: a novel system for analyzing differentiation from osteoblast to osteocyte. Bone 52: 102110 .

Verbruggen SW, Vaughan TJ, McNamara LM (2012) Strain amplification in bone mechanobiology: a computational investigation of the in vivo mechanics of osteocytes. J R Soc Interface 9: 2735-2744.

Wang D, Christensen K, Chawla K, Xiao G, Krebsbach PH, Franceschi RT (1999) Isolation and characterization of MC3T3-E1 preosteoblast subclones with distinct in vitro and in vivo differentiation/mineralization potential. J Bone Miner Res 14: 893-903.

Wang LS, Du C, Chung JE, Kurisawa M (2012) Enzymatically cross-linked gelatin-phenol hydrogels with a broader stiffness range for osteogenic differentiation of human mesenchymal stem cells. Acta Biomater 8: 18261837.

Wang L, Cowin SC, Weinbaum S, Fritton SP (2000) Modeling tracer transport in an osteon under cyclic loading. Ann Biomed Eng 28: 1200-1209.

Wang L, Wang Y, Han Y, Henderson SC, Majeska RJ, Weinbaum S, Schaffler MB (2005) In situ measurement of solute transport in the bone lacunar-canalicular system. Proc Natl Acad Sci USA 102: 11911-11916.

Wang Y, McNamara LM, Schaffler MB, Weinbaum S (2007) A model for the role of integrins in flow induced mechanotransduction in osteocytes. Proc Natl Acad Sci 104: 15941-15946.

Webster DJ, Schneider P, Dallas SL, Müller R (2013) Studying osteocytes within their environment. Bone 54: 285-295.

Weinbaum S, Cowin SC, Zeng Y (1994) A model for the excitation of osteocytes by mechanical loading-induced bone fluid shear stresses. J Biomech 27: 339-360.

Woo SM, Rosser J, Dusevich V, Kalajzic I, Bonewald LF (2011) Cell line IDG-SW3 replicates osteoblast-tolate-osteocyte differentiation in vitro and accelerates bone formation in vivo. J Bone Miner Res 26: 2634-2646.

You L, Cowin SC, Schaffler MB, Weinbaum S (2001) A model for strain amplification in the actin cytoskeleton of osteocytes due to fluid drag on pericellular matrix. J Biomech 34: 1375-1386.

Zaman MH, Trapani LM (2006) Migration of tumor cells in 3D matrices is governed by matrix stiffness along with cell-matrix adhesion and proteolysis. Proc Natl Acad Sci USA 103: 10889-10894.

Zeng Y, Cowin SC, Weinbaum S (1994) A fiber-matrix model for fluid-flow and streaming potentials in the canaliculi of an osteon. Ann Biomed Eng 22: 280-292.

Zhang K, Barragan-Adjemian C, Ye L, Kotha S, Dallas M, Lu Y, Zhao S, Harris M, Harris SE, Feng JQ, Bonewald LF (2006) E11/gp38 selective expression in osteocytes: regulation by mechanical strain and role in dendrite elongation. Mol Cell Biol 26: 4539-4552.

Zhou H, Weir MD, Xu HH (2011) Effect of cell seeding density on proliferation and osteodifferentiation of umbilical cord stem cells on calcium phosphate cementfiber scaffold. Tissue Eng Part A 17: 2603-2613.

\section{Discussion with Reviewer}

Reviewer I: In your previous work, evaluating the effect of cell density and material stiffness on osteocyte differentiation in 2D (Mullen et al., 2013), the authors showed that low cell density favoured osteocyte differentiation, while high cell density preserved osteoblast phenotype. Could the authors speculate why different results were achieved within the current manuscript evaluating osteocyte differentiation in $3 \mathrm{D}$ ?

Authors: In our previous work (Mullen et al., 2013) we studied cells seeded on a flat 2D surface at a low initial cell density of 1,000 cells $/ \mathrm{cm}^{2}$. The cells were shown to maintain a low cell density for the $14 \mathrm{~d}$ experiment. We proposed that the initial low cell density and the mechanics of the substrate together prevented cells from proliferating sufficiently and after a time resorted to extending processes to establish a communication network with neighbouring cells. However, in our 3D environment 2 million cells were initially encapsulated in a $1 \mathrm{~cm}^{3}$ volume of gelatinmtgase matrix. If all cells were successfully encapsulated and remained viable, we would expect an initially high cell density of approximately 16,000 cells $/ \mathrm{cm}^{2}$. However, we did observe that approximately $80 \%$ of cells were "dormant" at day 21 in the soft matrix stiffness at the high cell density group (data not shown), showing no normal cell activity (dendritic, motile, change in cell morphology, etc.) throughout the culture period, and these were excluded from further analysis. Therefore, the active population of osteoblasts/osteocytes might be closer to 3,200 cells $/ \mathrm{cm}^{2}$. Moreover, in the 3D environment the cells are confined on all sides by the gelatin-mtgase matrix, limiting the differentiation into osteocytes as the cells need to degrade the surrounding matrix to create space for dendrites. Thus, it is not possible to fully compare the cell densities between the $2 \mathrm{D}$ and $3 \mathrm{D}$ environments. However, the different results achieved within the current manuscript, i.e. high initial cell density favoured osteocyte differentiation, are likely explained due to a combination of the large population of inactive cells and the presentation of a 3D mechanical environment during cell encapsulation, which will place further spatial constraints on the extension of dendrites. Other studies have shown that cell encapsulation within a 3D matrix can prevent proliferation in cell types such 
as, cardiac cells, human embryonic stem cells and HepG2 liver cells (Lan et al., 2010; Soares et al., 2012; Tian et al., 2008).

Reviewer I: Did the authors see the formation of a surfacecell-layer already earlier than day 56 ? Could you speculate on the formation of this layer-de-differentation of cells, or just migration and subsequent cell proliferation?

Authors: A low confluency surface layer of cells was observed by approximately 20-30 d in the high cell density groups, whereas in the other cell density groups the surface layer formed at approximately 30-40 d. The surface layer of cells was not present at earlier time-points; however, a homogenous distribution of cells was observed throughout the hydrogel including cells encapsulated near the surface of the hydrogel after fabrication. Based on these observations, the authors propose that cells near the surface migrated out of the hydrogel and then started to proliferate at the surface, forming a confluent layer over the rest of the culture period.

Reviewer I: The authors report increased mineralisation in the high-cell-density group. Would the authors suspect an increase in matrix stiffness in this group that is superior over the other groups?

Authors: Mineral concentration is a key determinant of the mechanical properties of bone (Currey, 1984; Ruffoni et al., 2007). Increase in matrix stiffness due to mineralisation has been observed in silk scaffolds seeded with human bone marrow stem cells (Kim et al., 2007), polyurethane scaffolds seeded with MLO-A5 osteoblastic cells (Sittichockechaiwut et al., 2009) and also in peptide hydrogels containing encapsulated human osteoblasts cells (Castillo Diaz et al., 2014). Thus the authors would expect an increase in matrix stiffness compared to the other cell density groups at that stiffness.

Reviewer I: Could the authors speculate on the role of matrix stiffening during late osteocyte differentiation?

Authors: Osteocyte differentiation and matrix stiffness are inextricably linked. In vivo, osteoblasts primarily lay down a soft collagen matrix known as osteoid, onto which mineral crystals are subsequently deposited (BarraganAdjemian et al., 2006). However, there is a mineralisation lag time, which allows for osteoblasts to become embedded in the soft collagen matrix. During this time the osteoblasts transition into early stage osteocytes. Both osteoblasts on the surface and differentiating osteocytes release phosphate ions, which in turn results in mineral crystal growth and will hence the increase in matrix stiffness (BarraganAdjemian et al., 2006). The stiff calcified osteoid acts a mediator of mechanical stimulation to the osteocyte through load induced fluid flow and cell-ECM interactions within the lacunar-canalicular system (McNamara et al., 2009; Wang et al., 2007). Studies have shown changes in gene expression that coincide with mineralisation. Increased levels of early osteocyte markers, such as E11/gp38/podoplanin and dentin matrix protein 1 are expressed after the cell becomes embedded within the soft matrix and continues to increase with mineralisation along with sclerostin, a marker of the mature osteocyte, expressed when the cell is completely surrounded by dense calcified matrix (Bonewald, 2011; Dallas et al., 2013). It is intriguing to postulate that the development of a stiff matrix around the osteocyte and the ensuing change in mechanical stimulation would facilitate the terminal differentiation of the early stage osteocyte into an interconnected osteocyte that is mechanosensitive to its surrounding environment. However, as the change in matrix stiffness is itself caused by osteocyte differentiation future studies would be required to fully delineate the cause-effect relationships.

\section{Additional References}

Bonewald LF (2011) The amazing osteocyte. J Bone Miner Res 26: 229-238.

Currey JD (1984) Effects of differences in mineralization on the mechanical properties of bone. Philos Trans R Soc Lond B Biol Sci 304: 509-518.

Kim HJ, Kim UJ, Leisk GG, Bayan C, Georgakoudi I, Kaplan DL (2007) Bone regeneration on macroporous aqueous-derived silk 3-D scaffolds. Macromol Biosci 7: 643-655.

Ruffoni D, Fratzl P, Roschger P, Klaushofer K, Weinkamer R (2007) The bone mineralization density distribution as a fingerprint of the mineralization process. Bone 40: 1308-1319.

Sittichockechaiwut A, Scutt AM, Ryan AJ, Bonewald LF, Reilly GC (2009) Use of rapidly mineralising osteoblasts and short periods of mechanical loading to accelerate matrix maturation in $3 \mathrm{D}$ scaffolds. Bone 44: 822-829.

Tian XF, Heng BC, Ge Z, Lu K, Rufaihah AJ, Fan VT, Yeo JF, Cao T (2008) Comparison of osteogenesis of human embryonic stem cells within $2 \mathrm{D}$ and $3 \mathrm{D}$ culture systems. Scand J Clin Lab Invest 68: 58-67.

Editor's Note: Scientific Editor in charge of the paper: Martin Stoddart. 